\title{
EL FIN DE LA INFIDELIDAD O EPÍLOGO RAZONADO SOBRE LA CONQUISTA ESPIRITUAL EN LAS PROVINCIAS INTERNAS DE LA NUEVA ESPAÑA
}

\author{
Cecilia Sheridan Prieto \\ Centro de Investigaciones y Estudios Superiores \\ en Antropología Social
}

Habiendo discutido tanto los políticos para poder reducir a la civilización inmensas provincias de esta Nueva España, llevamos ya trescientos años y no hemos abonado casi nada.

Fray Mariano López y Pimentel ${ }^{1}$

\begin{abstract}
A finalizar el siglo xviII las misiones franciscanas locaAlizadas al noreste de la Nueva España parecían haber perdido el control que durante más de dos siglos mantuvieron sobre la población indígena nativa. Las condiciones políticas derivadas de la aplicación de las reformas
\end{abstract}

Fecha de recepción: 19 de enero de 2015

Fecha de aceptación: 9 de marzo de 2015

1 A partir de aquí, las referencias al plan de fray Mariano López y Pimentel corresponden al expediente "Colegio para la conversión de infieles de Asia y Américas, por medio de los mismos gentiles. Proyecto del Padre Pimentel, dieguino de México", s/f, BNE, SR, FA, Ms./3652, a menos que se indique lo contrario. 
emprendidas por los borbones transformaron los paisajes misioneros en zonas de poder militar y civil; una forma de secularización del paisaje que dejaba a las misiones al arbitrio de empresas privadas. ${ }^{2}$

Las misiones fundadas en sus orígenes con indios "insumisos", “apóstatas” y "salvajes”, habían sufrido síntomas de la secularización impuesta a las doctrinas. Los sínodos y limosnas les fueron reducidos o eliminados del todo, al mismo tiempo que a los misioneros se les culpó de ineficaces en sus tareas de conversión, o de "cerrados", por desdeñar la vecindad o cercanía de los españoles con los nativos. Se hacía referencia a una envejecida barbaridad que, junto con las fuertes críticas de civiles y militares, pusieron en tela de juicio los resultados de un largo proceso de transformación de los nativos por la vía de la evangelización. ${ }^{3}$

Gran parte de las misiones establecidas en el norte de la Nueva España desaparecieron gradualmente, al mismo tiempo que otras nacían bajo la égida de la colonización urgente

2 Osante, Orígenes del Nuevo Santander, ha trabajado en profundidad el fenómeno de la colonización del Nuevo Santander en el marco del proyecto de Escandón, una empresa de colonización característica de este proceso que involucró acciones misioneras. Más adelante, retomo otro proyecto de conversión, el del padre Alberola, que guarda estrecha cercanía con la idea de la conquista como empresa.

3 Al respecto, es interesante la interpretación de Hu-DeHart, "Rebelión campesina", en relación con la secularización de las misiones en el noroeste de la Nueva España, porque se emplean los mismos argumentos ofrecidos por los vecinos que en Coahuila y Texas pugnaban por la secularización: "argumentaban que era ya tiempo de que las misiones fueran traspasadas a curas seculares y de que los indios se integraran a la sociedad colonial y sirvieran a sus necesidades; después de todo, el ideal misionero original les daba a los misioneros 10, máximo 20 años, para pacificar, civilizar y preparar a las tribus de la frontera para su integración social”, p. 138. 
para contener a los indios. ${ }^{4}$ Los misioneros franciscanos, sin embargo, se mantuvieron en las nuevas misiones siempre bajo el principio original de la conversión al primitivo estilo misional: autónomos y autosuficientes, aun bajo la protección cada vez más limitada de los militares establecidos en los presidios. En el último empeño misional desplegado por los franciscanos al noreste de la Nueva España, las misiones se fundaban deliberadamente lejos de la población civil, que para los misioneros sólo desmerecía el arduo proceso de transformación de los indios infieles y apóstatas.

En un contexto de crítica y desencanto sobre la labor misional desplegada al norte de la Nueva España, ${ }^{5}$ surgió la

${ }^{4}$ Los procesos de secularización formal de las misiones jesuitas y franciscanas en el norte novohispano se dieron en diferentes momentos y de diversas maneras en cada provincia. En la de la Nueva Vizcaya, por ejemplo, Cristóbal Escobar y Llamas, como provincial de los jesuitas de Nueva España, en 1746 le propuso al rey Felipe IV la secularización de 22 misiones de Topia, Tepehuanes y la Baja Tarahumara porque ya no necesitaban del cuidado de los misioneros; la secularización se hizo efectiva en 1753, cuando las misiones se entregaron al obispo de Durango; véase Ortelli, Trama, p. 127. Para Sonora, véase el trabajo de Hernández SILVA, "Los pueblos yaquis", quien ubica la secularización de las misiones del Yaqui y el Mayo a partir de 1768, pp. 96-98. De la Torre Curiel, "Características de la empresa misional”, por otro lado, refiere a la Real Cédula de 1791 por medio de la cual se secularizaron algunas misiones de Sonora que se colaron en manos del clero diocesano: "la secularización en estas misiones al finalizar el siglo xviII no fue tanto el resultado de un decreto episcopal, como el reconocimiento a la inserción de dichas poblaciones en una dinámica ajena al control de los religiosos", pp. 61-63. ${ }_{5}^{5}$ Este contexto es parte de una política real que remite a la necesidad de proteger los territorios controlados al norte de la Nueva España con medios más drásticos que la conquista espiritual, como lo describe TORRE CURIEL, "Características" al hacer referencia a la preocupación del fiscal de la Audiencia de México, José Antonio de Areche, quien, en 1772, escribía al virrey Bucareli externando su preocupación por el estado de 
iniciativa del descalzo profeso de la provincia de San Diego de México, Mariano López y Pimentel, español originario de San Lúcar de Barrameda, de formar un "colegio de misioneros nacionales" para emprender la conversión de los “infieles” de la América hispánica y de Asia, que calculaba en millones.

Los planteamientos del fraile en torno a la necesidad de este ambicioso proyecto muestran, sin duda, cierta ignorancia sobre las condiciones de las misiones que aún se encontraban en funcionamiento en la extensa región que conformaban en ese momento las Provincias Internas, estructura político territorial creada en torno del afianzamiento de una frontera que demarcara con fuerza y poder real los límites de los territorios logrados, que el fraile toma como referencia inmediata para iniciar la salvación de los infieles de América.

El proyecto de fray Mariano fue remitido en 1808 al señor Marqués del Real Tesoro, don José Manuel de Villena y Palma ${ }^{6}$ para que lo presentara a la Junta Suprema de Sevilla y ésta, a su vez, lo recomendara a Fernando VII; un mes después de la jura del rey el expediente completo fue remitido de nuevo, el 19 de agosto de 1809.

decadencia al que habían llegado las misiones de Sonora, resultando ociosos "los trabajos y afanes de los misioneros, y superfluos los gastos que hacen a la Real Hacienda, como que no se conseguirá el fin y piadosas intenciones del rey en este asunto" (p. 49).

${ }^{6}$ Marqués del Real Tesoro, comandante militar de Marina del tercio y de la provincia de Sevilla, heredero de su tío Joaquín Manuel de Villena y Guadalaxara, quien fue presidente de la Real Audiencia de la Contratación de Cádiz. 
En este ensayo busco poner en contexto ese espacio que en el proyecto de fray Mariano representa la infidelidad, a partir de la justificación que sustenta o da fuerza a la idea central del dieguino: la salvación de millones de almas de América y Asia que corrían el riesgo de perderse para siempre a falta de misioneros y recursos. Como parte de la relación introduzco un breve análisis de la historiografía producida sobre el proyecto, relacionada con los empeños del fraile en el contexto de la transición política previa a la guerra de independencia, la manufactura del plan y la resulta de una intención cercana a la utopía o la locura.

En relación con la historiografía existente, sitúo la contribución de este trabajo en torno a dos cuestiones que justifican y dan sentido a la intención del fraile: por un lado la invectiva desatada en el siglo XviII en relación con los resultados de la conquista espiritual frente a sus costos monetarios y, por otro, la idea de la infidelidad como expresión de un proceso inacabado en América, que el fraile busca explicar a partir de las dificultades enfrentadas por los misioneros franciscanos en las misiones fundadas en el noreste de Nueva España.

En el análisis sitúo la noción de infidelidad contenida en el discurso del fraile como materia fundamental de su intención, que además justifica el método que se propone aplicar. Para ello, echo mano de otro proyecto poco conocido, pero no menos importante para la intención de este ensayo, que llamo el plan de Alberola, otro fraile, contemporáneo a fray Mariano, que me permitió analizar las semejanzas y discrepancias de dos empresas que parecieran partir de una misma intención: acabar con la infidelidad. Me interesa subrayar las discrepancias desde los métodos de conversión propuestos 
por cada uno y, en estos términos, ubicar la trascendencia de la propuesta del dieguino fundada en la diversidad lingüística y el reconocimiento subyacente de una importante heterogeneidad cultural entre los indios "infieles", habitantes de las Provincias Internas en Nueva España.

Las fuentes documentales que sustentan este trabajo se encuentran en diversos repositorios en España y México. El primer indicio del proyecto de fray Mariano lo leí por casualidad hace unos años en el Archivo de Indias, mientras buscaba documentación relativa a las misiones franciscanas establecidas en el norte de la Nueva España. Se trata de un impreso breve en el que se describe de manera pormenorizada la creación de un colegio de formación de misioneros: Extracto y compendio del plan de un seminario magno $y$ Colegio de misiones de varias lenguas, ciencias y artes para convertir a la fe y religión católica más de 660 millones de infieles, existentes en la Asia y América, y poderlos salvar a todos, segun la voluntad de Dios, ${ }^{7}$ que posteriormente volvía encontrar en la Biblioteca Nacional de España junto con otros tres cuadernillos anexos al manuscrito citado al inicio.

En dicho Extracto se encuentra un documento rubricado por fray Mariano López y Pimentel, titulado "Extractos y Compendios de la obra más interesante al bien de la Yglesia y de la Nación Española y sus Américas", que inicia con las dedicatorias respectivas y pasa de inmediato al "Proyecto práctico y piadoso para Conquistar a los gentiles por medio de los gentiles mismos sin exponer los intereses del Real Herario"; posteriormente aborda una "Breve idea de esta grande obra" $y$, finalmente, una serie de "notas y advertencias".

7 AGI, Audiencia de México, leg. 2736. 
Los impresos anexos al Extracto le sirven al fraile para hacer explícitos algunos de sus argumentos centrales, o subrayar los ya presentados. Estos son: "Cálculo de la población del mundo y los gentiles que mueren y se condenan por falta de Ministros del Evangelio, que los entiendan y conviertan en el Asia y las Américas"; el segundo es el mismo cuadernillo localizado en el Archivo de Indias ya mencionado, y el tercero es "La caridad del cristiano con los infieles y medio fácil de salvarnos todos". A éstos les sigue el "Manifiesto de la necesidad de un nuevo Colegio de Misioneros Nacionales de varios idiomas, ciencias y artes para civilizar y convertir a la fe y Religión Católica más de seiscientos sesenta millones de infieles existentes en la Asia y Américas", el cual a su vez contiene una serie de apartados: "mantenimiento"; "costo por menor de la manutención de los Niños"; "manifiestase la necesidad de este Colegio de Ydiomas, Ciencias, Artes y Oficios para la conversión de los Gentiles"; "utilidades de este Colegio de Misioneros Nacional de Ydiomas, ciencias y artes en compendio"; "conclusiones". Un tercer título, aparte de los anexos, "Clara y brebe instrucción de esta Obra" junto con "Extractos y apuntes de varios fondos y advitrios para que cualquiera cuerpo o comunidad pueda fundar este Colegio sin Gravamen de la Real Hacienda", se concentran en la viabilidad financiera y logística del plan. ${ }^{8}$

${ }^{8}$ Una parte del plan se encuentra digitalizada en línea como "Plan de Mariano López y Pimentel, religioso en la Provincia de San Diego de México, para la fundación de un colegio para convertir al catolicismo a 600000000 de infieles en Asia y América y reglamento del mismo", 1808, AHN, Estado, N. 175 a N. 178 (imagen 237-248), América. Impresos de América, 54, 1; disponible en línea en: http://pares.meu.es/Bicente- 
El "Reglamento", también localizado originalmente en el Archivo de Indias, consiste en una especie de manual pedagógico para la formación de ministros de la Iglesia aptos para misionar entre los infieles de Asia y de las Provincias Internas de la Nueva España. A éste le siguen los planos del edificio, de manufactura neoclásica, diseñado en dos plantas con capacidad para albergar a 2000 "infieles".

En el grueso del material analizado no encontré secuencias por fechas y sí una serie de reiteraciones que hacen evidente la confección del proyecto en escenarios y tiempos distintos. La manufactura de los documentos, sin embargo, resulta consistente con el plan de conversión que se propuso el dieguino, más allá del juicio de sus contemporáneos, que calificaron de descabellada la propuesta. Lejos de dar pie a una discusión inútil sobre la confiabilidad del fraile en relación con las expectativas que generó el ambicioso proyecto, es indudable que éste trabajó arduamente en el diseño, los objetivos y la viabilidad del mismo, en un contexto político adverso a las utopías renacidas de la conquista espiritual.

narioindependencias/catalog/description/6170155. En librillo empastado se encuentran completos los cuadernillos impresos, así como el manuscrito de presentación inicial firmado por fray Mariano López y Pimentel, como Proyecto de creación de un Colegio para la conversión de infieles de Asia y Américas por medio de los mismos gentiles, disponible en línea en: http://bdh-rd.bne.es/viewer.vm?pid=d-3612301.

9 AGI, Estado, 41091. AGI, MP-MEXICO, 498. "Plano Real del Colegio de Infieles Nacionales. Misiones de Provincias Internas”, agosto 19 de 1809. El mismo plano está referido en Torres Lanzas, Relación descriptiva de los mapas, planos, como "Plano del Real Colegio de Infieles Nacionales. Misiones de Provincias Internas para educación de hijos de infieles", p. 138. 
LA HISTORIOGRAFÍA RELATIVA AL PLAN DE PIMENTEL

Tras una revisión extensa localicé cinco ensayos dedicados a analizar el plan propuesto por fray Mariano, además de referencias aisladas en otros trabajos. El primero de estos ensayos, publicado en 1952, "Un proyecto del Colegio Magno de Misioneros en Mejico", de la autoría de Victoria Hernández Almendros, hace especial énfasis en los planos arquitectónicos y la belleza del diseño neoclásico de la fachada del edificio, que son, sin duda, fascinantes por la lógica que se presume pragmática en cuanto a la organización de un espacio de reducción para la conversión. La autora se pregunta asombrada: "¿dónde se iba a ubicar este Colegio, nueva torre de Babel de las 'Naciones Unidas' por el catolicismo?", conmovida, sin duda, por el esfuerzo del fraile, que califica de "desinteresado y hermoso" ${ }^{10} \mathrm{El}$ trabajo describe con evidente entusiasmo lo que la autora evalúa como una labor extraordinaria de los franciscanos en sus empeños por la evangelización en el plano global.

En un trabajo posterior, de Elizabeth A. H. John, publicado en 1992, "The Multilingual Vision of Fray Pimentel", el énfasis se pone en la idea del fracaso misional entre los nativos del norte novohispano, específicamente en Texas y en la Nueva Vizcaya, para explicar el fundamento del proyecto del fraile. Aun cuando su interpretación se aleja un poco del trasfondo que el dieguino le otorga a la necesidad de hacer concurrentes diversas "naciones" de Asia y América en un mismo espacio, que, por cierto, conforma una de las reglas básicas del humanismo europeo que propugnaba

10 Hernández Almendros, “Un proyecto”, pp. 415 y 424. 
el intercambio cultural ${ }^{11}$ y que es el principio de la enseñanza que el fraile se propone, John enfatiza la cuestión lingüística y el mantenimiento de la lengua de los futuros misioneros como la característica excepcional del plan propuesto por fray Mariano:

The crux of Pimentel's proposal was that the comprehensive program be carefully structured to assure that the students retain proficiency in their native languages. To the end, each nation must have its own separate quarters at the College in wish to live and work and study, so as to continue speaking their own tongues among themselves. ${ }^{12}$

Una década después, Marcela Corvera Poiré publicó un capítulo de su tesis de posgrado, "Soñando con evangelizar: el colegio de infieles proyectado por fray Mariano López Pimentel (1808-1813)". ${ }^{13}$ En el contexto de un trabajo más amplio, tocante a la historia de los franciscanos descalzos de la Provincia de San Diego, Corvera Poiré califica de "utópico" el proyecto de López y Pimentel para centrar su interés en la personalidad del fraile, sin ahondar en el contenido del proyecto o en el porqué del mismo. El análisis

\footnotetext{
${ }^{11}$ Dingping, "La relación", p. 68.

12 "El punto crucial de la propuesta de Pimentel es que el programa fuera estructurado cuidadosamente para asegurar que los estudiantes conservaran sus idiomas originarios. Para ello, cada nación tendría en el colegio su espacio separado de los demás para vivir, trabajar y estudiar; un ambiente que les permitiera hablar entre sí en sus propias lenguas" (trad. libre). JoHn,"The Multilingual", p. 153.

${ }^{13}$ El trabajo de Corvera Poiré, en su versión original, constituye el capítulo 7 de su tesis doctoral. Corvera Poiré, "Estudio histórico", defendida en la Universidad Complutense de Madrid en 1995.
} 
está orientado a destacar la diversidad de los dieguinos y su historia en diversos contextos religiosos y misionales.

En 2006, Laura Hillock Damm publicó el ensayo "La frontera que nos une: proyecto para educar al bárbaro, México, 1807", ${ }^{14}$ como parte de una tesis de posgrado. Hillock intenta orientar su análisis al contexto político y social del norte novohispano que sintetiza en la idea, o certeza, de que se trataba de un espacio habitado por indios "bárbaros", materia de conversión de los misioneros franciscanos. Las fuentes que sostienen esta propuesta se limitan a la información contenida en algunas crónicas clásicas del siglo XviII, como la de fray Isidro Félix de Espinoza (1746) y el compendio de Pedro Alonso O'Crouley (1774). Hillock analiza las intenciones de los misioneros franciscanos sobre esa masa indígena que le parece poco maleable e inconstante "para adoptar las nuevas costumbres asociadas con el vivir civilizado" y que coloca como el contexto que inspiró el empeño de fray Mariano López y Pimentel para desarrollar el plan del colegio de misioneros. ${ }^{15}$ Más allá de las generalizaciones y lugares comunes asociados a la idea de un norte bárbaro, Hillock justifica la intención del fraile derivada de la experiencia de éste en la conversión de infieles, puesto que había ejercido como misionero en la región de Aguascalientes.

El trabajo más reciente, sustentado sobre sólidas bases, de análisis en torno de la misionaria en Asia es el de Francisco

${ }^{14}$ Por instrucción de la autora, la página de tesis electrónicas de la Universidad de Chile sólo menciona el título pero no la publica. Ella misma cita que la tesis fue publicada por el Archivo Franciscano de Santiago de Chile en 2007, con el núm. 97, pero tampoco fue posible acceder al documento.

${ }^{15}$ Hillock, "La frontera”, pp. 67 y 75. 
Morales, O.F.M; "De la utopía a la locura. El Asia en la mente de los franciscanos de la Nueva España: del siglo xvi al XIX" (2008). A partir del análisis de la influencia del mundo asiático en el origen y posterior desarrollo del pensamiento franciscano en su actuación misionera, Morales vincula el proyecto de fray Mariano López y Pimentel a las percepciones culturales franciscanas de la misionaria en Asia. La perspectiva de la contraparte misionera en Asia coloca el plan del fraile en el propio contexto de la discusión de su tiempo respecto a la acción misionera franciscana en el ámbito global. ${ }^{16}$ Morales encuentra en el "imaginario misionero" el ideal del franciscanismo novohispano, como expresión de "la corriente más estricta del franciscanismo español del xvı", el cual pugnaba por un estilo de vida basado en el radicalismo evangélico y el eremitismo contemplativo. En este imaginario China se convierte en un destino más que atractivo para los evangelizadores influenciados por el espiritualismo de Martín de Valencia, quien fuera superior en la expedición de los primeros franciscanos que arribaron a México en $1524,{ }^{17}$ quien soñaba, literalmente, con la evangelización de los "infieles"

16 Antes del siglo xvi hubo diversos intentos de los frailes franciscanos por evangelizar a China. En 1267 el italiano Giovanni da Montecorvino se reconoce como el primer fraile que llegó a Beijing a raíz de la solicitud que hizo el emperador chino a Roma para que los misioneros franciscanos evangelizaran en China. A partir de la decadencia de la dinastía mongol y del nacimiento de la dinastía Ming, se abrió un largo periodo de tres siglos de ausencia de la misión franciscana hasta 1579, en que ingresaron tres frailes de las Filipinas a China en una estancia de apenas cuatro meses. A partir de ahí, los misioneros se movieron por diversos países asiáticos, como Corea, Taiwan y Japón (Menghsuan KU, s/f). Sobre la misionización franciscana en Asia véase DingPing, "La relación".

${ }^{17}$ Sobre la vida espiritual de fray Martín de Valencia véase Gómez CaneDo, Evangelización y conquista. 
de Oriente, cuestión que se hizo realidad a finales del siglo xvI con la fundación de la provincia de San Gregorio en Filipinas, "pie de playa para entrar a Japón y China". ${ }^{18}$

El énfasis de Morales está puesto en la explicación de la mutua influencia entre la labor misional en Asia y la de Nueva España, intermediaria esta última en el suministro de misioneros de diversas órdenes enviados a Asia. ${ }^{19} \mathrm{El}$ trabajo de Francisco Morales abre el contexto de la propuesta de fray Mariano quien, al igual que los misioneros de otras órdenes, sin duda era consciente de los alcances y frustraciones de la labor misionera en Asia y América.

\section{LA JUSTIFICACIÓN DEL PROYECTO DE PIMENTEL}

La justificación del plan de fray Mariano se sustenta en lo que parecería ser un lugar conocido, es decir, la crítica contundente a la labor misionera desplegada por más de dos siglos en las Provincias Internas de la Nueva España: el gran fracaso de la anhelada conquista espiritual entre los "bárbaros” se subsanaría en la seguridad de su redención y la

${ }^{18}$ Morales, "De la utopía a la locura”, pp. 68 y 70.

${ }^{19}$ La idea de América y Asia como fuente fundamental de la labor misionera se puede apreciar representada en San Francisco Xavier como patrono de los misioneros, en un óleo de Antonio de Torres (1720), titulado San Francisco Xavier cargando a un indio, localizado en la Pinacoteca de la Iglesia de la Profesa, en la ciudad de México, "como lo vio en un sueño": el indio tiene rasgos americanos y atributos orientales y en el fondo se aprecia una escena de "indios salvajes" que De Alba-Koch asegura es "un reconocimiento a la nada fácil evangelización del norte del virreinato", sustentada en un "modelo de cristianización" que misioneros franciscanos y jesuitas aplicaron en Asia. De Alba-Koch, "La grandeza mexicana", pp. 18 y 26. 
consecuente influencia de los indios transformados sobre sus congéneres para impartir el Evangelio en su lengua. El plan, colocado en la vía de la "enseñanza” y del aprendizaje de las ventajas que ofrecía la civilización, parece alejarse del método primitivo de la conversión masiva de los indios en sus lugares de origen, reducidos a las misiones en las que con el tiempo eran transformados. Esta distancia parecería un asunto meramente práctico que ahorraría mucho dinero al erario y salvaría el escollo de la falta de misioneros en formación dispuestos a misionar entre bárbaros, ya que los nativos serían trasladados al colegio para hacerlos volver años después transformados en misioneros.

Se aprecia, además, una diferencia de fondo en los resultados a largo plazo que consiste, principalmente, en mantener la lengua originaria de los infieles, así como sus costumbres alimenticias y de vestido, con el objeto de salvaguardar su identidad, que sería el motor de la conversión al recibir los infieles in situ el conocimiento divino de parte de los suyos y en sus lenguas. Sobre los nativos de las Provincias Internas, el objeto primerísimo del plan serían los indios nativos hijos de los "enemigos" apóstatas y miembros de esa "envejecida barbaridad" a la que las autoridades preferían ver sujeta al amparo de los misioneros y los soldados.

Entre los argumentos expuestos por fray Mariano en favor del proyecto como posibilidad de una conversión real, enfatiza el proceso de administración del bautizo, un tema polémico entre los mendicantes que refleja, según su parecer, la expresión del fracaso evangelizador en las Provincias Internas. De nada servía el trabajo que el misionero invertía en la enseñanza del Evangelio para imponer el bautizo, ya que al no hablar su lengua, los nativos sólo habían 
aprendido algunas oraciones de la doctrina y el catecismo en castellano: "estos indios, que solo saben de memoria y sin saber su contenido ni espíritu, la saben como los pericos, loros y papagayos, sin entender lo que dicen ni creer en Dios, y bautizados en este estado, son solo cristianos en el nombre y así, con facilidad, se vuelven a sus idolatrías y supersticiones antiguas".

Por otro lado, además de lo que se calcula fueron millones gastados por la corona en el mantenimiento de las misiones y presidios, agrega una fuerte crítica a los resultados obtenidos en relación con el gobierno temporal y la vida civil y política de los nativos. En un juicio sin duda insuficientemente fundado, además de hábilmente orientado a exaltar el fracaso misional, el fraile argumenta en torno a que ni los misioneros ni los soldados entendían de artes y oficios, por lo que no lograban levantar los edificios necesarios para hacer un pueblo civil y político que alentara asentamientos más definitivos, provocando con ello que los indios acabaran viviendo en chozas o jacales, "poco menos que los animales en sus cuevas y en perpetua ociosidad". Esto, desde su perspectiva, motivaba a los neófitos a fugarse de las misiones para volver "a los montes y cerros a su antigua vida para tener que comer sus raíces y frutos silvestres y los animales que con sus flechas pueden matar pues el Yndio Gentil nada sabe hacer más que correr y salir en busca de animales que comer y comido éste acostarse a dormir”. ${ }^{20}$

${ }^{20}$ Esta idea de la inconsistencia de las misiones adjudicada a la falta de edificios y demás cuestiones relacionadas con su funcionamiento es, sin duda, exagerada. A la fecha se mantienen en pie capillas, iglesias y trazas de misiones y pueblos en diversos lugares de México y Estados Unidos 
Para fray Mariano los infieles representan dos terceras partes del mundo; su referente más cercano a la condición de ser "infiel" lo toma de la información extraída de crónicas, informes y, seguramente, documentos comentados por hermanos y conocidos, en relación con las dificultades de la conversión en las llamadas Provincias Internas. En la misma medida, a los infieles de Asia los coloca en un universo culturalmente impreciso que engloba en China, y las dificultades de la conversión en esa parte del mundo que conoce por los escritos del padre Claudio Francisco Letondal. ${ }^{21}$

En este sentido, en la construcción de sus argumentos, sin duda cercanos a las ideas ilustradas de la época, para el fraile las Provincias Internas eran el contenedor de una especie de infidelidad agotada, sólo recuperable a partir de la educación de los niños en la enseñanza de las artes y las ciencias como táctica para crear condiciones a futuro, en donde los indios serían convertidos a la fe por sus congéneres logrando así una empatía natural: misioneros nacionales, en el sentido de su pertenencia a una "nación". En el caso de los niños asiáticos el proyecto los coloca como medio de contraste para que los infieles nativos de las Provincias Internas aprendieran de ellos las buenas costumbres de una cultura que el dieguino respeta pero sabe infiel por la carencia de misioneros.

de América, desde Querétaro hasta Texas, e incluso Florida. Al respecto véase Sheridan, Anónimos y desterrados.

21 Letondal, autor de la Relación de las tribulaciones de los fieles, miembro de la congregación de San Vicente de Paul, nació en Francia en 1753 y trabajó como procurador de las misiones en China. En 1803 llegó a México en busca de limosnas para mantener vivas dichas misiones. 
A partir de la propuesta de Francisco Morales (2008), es necesario destacar algunos aspectos del plan de fray Mariano que podrían vincularse a cierto modelo de cristianización iniciado formalmente por Felipe II cuando envió una embajada imperial a China con el objetivo de promover la evangelización en ese país. La misión no logró llegar a su destino pero, a partir de entonces, China se convirtió en el referente de la evangelización para diferentes órdenes que fueron enviadas a China por la ruta de la Nueva España, alterna a la de Portugal. ${ }^{22}$ En 1633, Antonio Caballero, acompañado de una treintena de misioneros franciscanos, llegó a Fuan después de permanecer unos años en Filipinas, sentando las bases de la misión franciscana en China:

Durante el régimen del emperador Shunzhi, el padre Caballero partió desde Fujian hacia el norte, y al final, llegó a Jina de Shandong. Eso inició la misión franciscana de Shandong. Hasta el régimen del emperador Kangxi, durante el cual llegaron más franciscanos, la misión cristiana fue dominada por dicha orden, de modo que paulatinamente vinieron menos jesuitas. ${ }^{23}$

En la práctica surgieron importantes divergencias sobre la estrategia de evangelización entre jesuitas y mendicantes, las cuales dieron origen a la controversia de los ritos, o definición de la distancia entre el rito como religioso y por tanto idólatra, y el rito como acción civil. Las controversias

${ }^{22}$ De acuerdo con Dingping, “La relación”, p. 52, en una carta dirigida al emperador chino, el rey de España declaró que su único objetivo era "enseñar al emperador chino y su pueblo el camino hacia el honorario y respetuoso Creador del mundo".

${ }^{23}$ Liang Quichao (1996), citado por Dingping, “La relación”, p. 54. 
fundamentales parecen estar presentes en el proyecto de fray Mariano, quien se manifiesta en favor de la evangelización por la vía pacífica sin el uso de las armas y que el fraile expone como medio para granjearse "la simpatía de la gente mediante la propagación de las ciencias avanzadas"; propuesta que se apega a la tradición humanista europea que ve con buenos ojos el intercambio cultural, que en América se identifica con fray Bernardino de Sahagún, principalmente.

De ahí el empeño del dieguino por mantener viva la cultura nativa en el proceso de aprendizaje de la cultura cristiana $y$, en consecuencia, la lengua originaria como medio a futuro para la evangelización in situ; cuestión que en el método jesuita de la evangelización en China fue visto por la Inquisición como un impedimento para "la exacta comprensión de las sacras fórmulas" debido a la polisemia del chino. ${ }^{24}$

\section{LA CONQUISTA ESPIRITUAL: ¿UNA CONQUISTA FALLIDA?}

En su "Breve idea de esta grande obra", López y Pimentel se refiere a la "gran empresa de nuestros mayores" en un reconocimiento explícito a la intención civilizadora de la acción misionera franciscana, pero sin eximirla del fracaso en la conversión de un mundo de infidelidad al que, por diversas razones, valora como argumento en favor de su proyecto: por un lado, la que define como "desconfianza" de los indios frente a los padres misioneros porque éstos no hablaban su lengua, la considera un factor central del "fracaso", ${ }^{25}$

${ }^{24}$ Consi, “¿‘Obreros de la viña’ o savants?”, p. 547.

${ }^{25}$ La crítica en relación con el aprendizaje o no de las lenguas nativas en el norte de la Nueva España fue reiterativa en los siglos xvir y xviII, tanto de las autoridades eclesiásticas como de las civiles. Sin duda, este era un 
por otro, la carencia cada vez más evidente de misioneros dispuestos a misionar entre infieles.

En la evaluación que hace fray Mariano, parece evidente que abrevó en documentación relacionada con la realidad misional de las Provincias Internas ya que, aunque no tuviera un panorama claro derivado tal vez de la enorme diversidad de situaciones por las que pasaban las misiones en los últimos años previos a la elaboración de su proyecto, reconocía que el proyecto original de la conquista espiritual se hallaba en indiscutible declive.

Es importante anotar algunas cuestiones de contexto que forman parte de la documentación generada a lo largo de los siglos XVI-XVIII en relación con las misiones franciscanas establecidas entre los indios nómadas nativos del noreste novohispano, sus métodos, posibilidades y entorno social y político, para ubicar con mayor claridad la interpretación del fraile. A lo largo de estos siglos las misiones sufrieron una serie de cambios, tanto en su ubicación como en su permanencia, que pueden asociarse a factores muy diversos: desde la ubicación, por ejemplo, que no siempre resultaba ser la

problema derivado de la enorme diversidad de lenguas que se hablaban en regiones del noreste, pero también estaba relacionado con la dificultad que algunos misioneros tenían para aprenderlas. Una acusación drástica al respecto es la que hizo en 1694 el gobernador de Nuevo México, Pedro Rodríguez Cubero, en relación con el levantamiento de los indios pueblo en 1680, debido, según él, a que los misioneros no conocían las lenguas de los indios. Véase VÁzquez Loya, Las misiones franciscanas en Chibuabua, p. 38, quien abunda en ejemplos sobre esta situación y a la vez menciona tres gramáticas desarrolladas por franciscanos entre los siglos Xvi y XIx: la gramática concha de fray Juan de Espinoza, a finales del siglo xvi; la gramática suma de fray Jerónimo de Virvez en el siglo xviI, y la tarahumara de fray Miguel de Tellechea en 1826. 
mejor debido a cuestiones como la feracidad de la tierra o el acceso al agua de riego pero, sobre todo, a la "mortal enemiga”, es decir, la inseguridad a la que se encontraban expuestas por ubicarse en territorios de indígenas contrarios a los españoles, o contrarios a los mismos indios que se encontraban reducidos y, por lo tanto, verse atacadas con insistente frecuencia. No era extraño, entonces, que las misiones sufrieran traslados continuos o que, en el peor de los casos, dejaran de funcionar abandonando los misioneros el lugar.

Otro aspecto, ciertamente común, estaba relacionado con que los indios reducidos abandonaran la misión antes de las cosechas instigados por los propios frailes para que buscaran sustento en el entorno, ahorrando así a las misiones los gastos de manutención. En general los indios no volvían a la misma misión; se dispersaban en otras misiones o simplemente se quedaban a vivir en sus territorios de origen, apurando a los misioneros a seguirlos, o a buscar nuevos grupos indios cuando no lograban dar con los que ya habían sido reducidos previamente y que, casi de inmediato, pasaban a formar parte de los inventarios misioneros como idólatras, apóstatas e infieles. ${ }^{26}$

Las enfermedades introducidas en el proceso de conquista y colonización de los territorios nativos formaban parte igualmente de la explicación de la inestabilidad de los asentamientos misionales. De la noche a la mañana éstas podían acabar con los indios reducidos provocando que la misión despareciera temporalmente o de manera definitiva si no era posible poblarla de nuevo. ${ }^{27}$ Cuestiones como la muerte del

\footnotetext{
${ }^{26}$ Véase SHeridan, Anónimos y desterrados.

27 En 1739, el gobernador de la provincia de Coahuila, don Clemente de
} 
o de los frailes encargados de la misión, la injerencia constante de los encomenderos y de las autoridades militares, el retraso en el envío de sínodos, y muchas otras que formaron parte del cotidiano devenir de la vida misional, también describen las particularidades de la acción misionera.

Pero la cuestión que me parece más relevante para comprender el contexto del plan de fray Mariano es la secularización paulatina que sufrieron la mayoría de las misiones del norte en la segunda mitad del siglo xviII, a partir de los argumentos contenidos en la real cédula expedida por el rey el $1^{\circ}$ de febrero de 1753 , que mandaba la secularización de las doctrinas. Un ejemplo claro al respecto es el de la demanda del obispo don Pedro Tamarón y Romeral quien, en 1760, realizó una visita pastoral a Nuevo México, de la que derivó una petición al rey, sustentada en la real cédula de 1753, de la entrega de cuatro misiones (Paso del Norte, Santa Cruz de la Cañada, Albuquerque y Santa Fe) de la custodia para transformarlas en curatos. ${ }^{28}$

El proceso de secularización desatado en el norte de la nueva España favoreció, sin duda, el incremento de la tensión política de larga data en las relaciones entre las autoridades civiles y militares frente a la autoridad de los misioneros, y de éstos con cualquier otra autoridad ajena a las empresas de conversión. Un caso destacado que ilustra esta situación es el de las campañas políticas emprendidas por

la Garza Falcón, en una consulta que hizo al virrey Conde de Fuenclara le menciona la "extinción" de los indios de tres misiones debida a una epidemia de viruelas. Igualmente se menciona la desaparición de los indios de una misión en Coahuila en una relación sobre las misiones del Río Grande del Norte. Véase Sheridan, Anónimos y desterrados, p. 349.

28 Véase Vázquez Loya, Las misiones franciscanas en Chibuabua, p. 91. 
el gobernador de la provincia de Coahuila, don Pedro de Rábago y Therán (1744-1754), contra las misiones y sus misioneros, bajo el argumento de la incapacidad de los franciscanos para pacificar la región y transformar a los indios nativos en pobladores pacíficos, obedientes de Dios y del rey. Para el gobernador, aliado con los vecinos españoles y con los capitanes de los presidios, la única manera de controlar a los indios "apóstatas" eran las armas. Los vecinos estaban dispuestos a arriesgar la vida si el virrey les concedía "la distribución del interés de los despojos y presa chica de dichos enemigos, con la obligación de educarlos y de enseñarles la doctrina cristiana". ${ }^{29}$

En 1746, los misioneros de la provincia franciscana de Jalisco defendieron la importancia de su labor como medio para contener el crecimiento de la apostasía e integrar nuevos infieles a las misiones vivas, con una serie de representaciones dirigidas a diversas autoridades virreinales y peninsulares. Confirmaban que en las siete misiones activas y bajo su cuidado (San Francisco Solano, San Bernardo, San Buenaventura, Santa Rosa de Viterbo de Nadadores, Valladares, Santo Niño de Jesús de Peyotes y San Francisco Vizarrón) se hallaban congregados 1210 nativos, mientras que el gobernador afirmaba que se trataba de una cifra exagerada ya que, según sus cálculos, los indios reducidos sumaban únicamente 447.

Lo cierto es que a raíz del informe externado por el gobernador, el Marqués de Altamira, como auditor de guerra, determinó reducir de inmediato los sínodos por estar las misiones casi despobladas. Un año más tarde, el

29 Sheridan, Anónimos y desterrados, p. 200. 
virrey decretó la prohibición del pago hasta contar con información veraz y detallada de los padres provinciales de las provincias franciscanas de Jalisco y Zacatecas. La idea de cortar las limosnas y sínodos ya había sido propuesta en 1744 por el gobernador de la colonia del Nuevo Santander, José de Escandón, quien argumentaba que era el momento de transformar las misiones en curatos o doctrinas "por haberse extinguido los indios". 30

En 1747 las misiones de la provincia de Coahuila se redujeron a tres, mientras que las diez misiones del Nuevo Reino de León, administradas por la Provincia Seráfica de Zacatecas, a dos. Las misiones de Río Grande y Texas sobrevivieron al embate de la secularización debido a su importancia fronteriza frente a la amenaza de los intereses franceses y de los indios infieles no reducidos a misión.

Una década más tarde, en diversos informes dirigidos a fray Manuel de Nájera, comisario general de la provincia franciscana de Jalisco, entre 1761 y 1762, daban cuenta de la evidente decadencia de las misiones que este colegio mantenía en el norte de la Nueva España: cinco en la provincia de Coahuila y el resto en Nayarit. En Coahuila únicamente la misión de Vizarrón había logrado mantener reducidos a más de 80 indios de las naciones pausán y piguigue y 170 "indios montaraces sin propiedad ni domicilio", mientras

30 SHERIDAn, Anónimos y desterrados, p. 349. El rey aportaba los sínodos o estipendios anuales de los misioneros y las limosnas para el culto en regiones de conversión en las que no se recibían diezmos u obvenciones; la cantidad aportada por la corona dependía de diversos factores, pero generalmente se enviaban las mismas cantidades a las misiones del norte de la Nueva España. Al respecto véase Arricivita, Crónica seráfica y apostólica, p. 401. 
que el resto de las reducciones habían decaído sin remedio. La causa principal, decían los misioneros, era que los franciscanos del Colegio de la Santa Cruz de Querétaro habían detenido el acercamiento voluntario de los indios de Texas al haber fundado dos misiones en la "frontera del barbarismo". ${ }^{31}$

Aun así, y pese a que el proyecto de secularización fuera respaldado por don Joseph de Escandón, al finalizar el siglo XviII las misiones establecidas en el Nuevo Santander como parte del proyecto de colonización emprendido por el asturiano mantenían vivas diversas misiones en las regiones más conflictivas del territorio santanderino. En la real cédula del 21 de mayo de 1747, se requirió a los misioneros que dieran cuenta de las misiones y pueblos que conformaban las custodias describiendo sus orígenes, antigüedad, los nombres de los frailes muertos, la necesidad de nuevos religiosos "para que no padezca de detrimento la propagación de nuestra Santa Fe y conversión de los fieles", las misiones capaces de transformarse en curatos o doctrinas y las limosnas anuales recibidas por los frailes, datos que el rey requería para "aclarar la mente sobre el tema de las misiones". 32

En los siguientes años, las autoridades eclesiásticas de la Provincia de San Pedro y San Pablo continuaron ordenando informes semejantes en los que se enfatizaban situaciones límite para la vida de las misiones, tales como la falta de recursos mínimos para su manutención y la de los indios. Como se aprecia en la respuesta del custodio de Santa

${ }^{31}$ Sheridan, Anónimos y desterrados, pp. 211-212.

32 AGOFM, M. Missioni, 32, t. 3030, f. 211, "Noticias de las misiones de Tampico, número y demás conducente a las familias”. 
Catarina de Río Verde, con fecha de 1758, fray Miguel de Santiesteban, a la consulta realizada por el comisario general: aseguraba que todas las misiones de dicha custodia contaban con al menos un misionero de continua residencia y ninguno por temporada, excepto la misión de San Miguel de los Ynfantes, que estaba por extinguirse de no ser porque el capitán de dicha población alimentaba al fraile en su propia mesa esperando que se lograran las cosechas de maíz de las que se mantenían los indios "neófitos", que "por lo general son dichos Yndios inútiles, sumamente perezosos y amigos del ocio, y más aprecian andar fugitivos por las sierras incultas, manteniéndose de raíces, agua o miel, y carnes inusitadas, que sujetarse al trabajo y enseñanza de la Ley de Dios". ${ }^{33}$

Desde la perspectiva secular, la vida de las misiones y su efectividad contrastaba fuertemente con la de los misioneros en campo, como puede observarse en la Instrucción reservada al Marqués de Branciforte (1794), en donde el Conde de Revillagigedo aseguraba que en relación con las misiones vivas de la Provincia de Coahuila, "la porción de indios reducidos" era muy corta pese a que desde el establecimiento de la primera misión en 1676, "para mantenerlas, sosegar inquietudes de los mismos indios con tropas volantes y presidiales, y conservar el dominio de un dilatado país, que aunque cubierto de numerosa gentilidad, nunca ha sido posible atraerla a la religión y vasallaje", el rey había erogado "millones" y, aun así, "solamente han quedado unos cor-

33 AGOFM, M. Missioni, 32, t. 3030, ff. 96-106, "Noticias de las misiones de Tampico, número y demás conducente a las familias". 
tos restos de aquellas naciones, con la confusa memoria de sus nombres". ${ }^{34}$

Apenas un año después de la Instrucción de Revillagigedo, en 1795, Félix María Calleja, quien fungía como inspector de las Provincias Internas en el Nuevo Reino de León y colonia del Nuevo Santander, envió al virrey un pormenorizado informe sobre los indios y naciones que se buscaba reducir en pueblos y misiones en la Nueva Tamaulipa. ${ }^{35}$ La tardía colonización de esta área del noreste novohispano atrajo un sinnúmero de nativos que buscaban los beneficios de la reducción (protección, regalos, alimento), aun cuando ya habían vivido tiempo atrás, e incluso habían sido bautizados, en otras misiones en Chihuahua, Coahuila, Texas y el Nuevo Reino de León.

El recuento de Calleja muestra que, efectivamente, buen número de nativos, que contabilizó en 2190 "gentiles de ambos sexos y todas edades", podrían ser controlados por los misioneros en las ocho misiones existentes dependientes de curatos y cuatro misiones independientes; mientras que para los “indios enemigos” reservaba un "informe general sobre el modo de hacer la guerra a los diferentes indios enemigos, examinando su número, situación, carácter y demás circunstancias" que en el Nuevo Reino de León y Texas se componían de más de 2000 "gandules”. Mil de ellos eran apaches bien armados "sagaces y al exceso faltos de buena fe"; 180 apaches mescaleros "a pie, desnudos, armados de escopeta y lanza, más salvajes que todos”; 500 comanches

\footnotetext{
${ }^{34}$ Revillagigedo, Informes sobre las misiones, pp. 60-61.

35 Calleja del Rey, "Informe sobre la Colonia”. A partir de aquí las referencias al informe corresponden a este documento.
} 
“armados, montados, cubiertos de una piel de cíbolo por todo traje, de carácter feroz e intrépido” y, por último, 830 nativos de las naciones de texas tancagues, carancaguases y taguayases quienes, desde su punto de vista, eran "los menos perjudiciales”. En la Tamaulipa Oriental registró 420 “gandules” de varias naciones que clasificó como “enemigos de inferior especie en calidad y número pero superiores por situación”. En las misiones, como “personas reducidas”, contabilizó 2458 "sin que ningunas hayan contraído ideas religiosas ni costumbres civiles y sociales”.

Con ese inventario, el dictamen de Calleja se orientaba a reforzar la idea de que las misiones, aun cuando se trataba de "pequeñas sociedades cristianas y políticas", habían demostrado su incapacidad para contener a los indios y mucho menos para civilizarlos. El dictamen final del inspector demuestra, sin duda, el cierre de un largo y accidentado proceso de secularización, así como la intención de devolver el poder militar a las zonas de conquista: "todo salvaje es infiel en sus promesas, ladrón y sanguinario por carácter y costumbre, lo mismo en Asia que Europa y América, y para hacerles pasar de este estado al de civilidad no se ha hallado otro medio que el de rigor alternado con la humanidad. Todo país de conquista lo necesita para evitar mayores daños".

Al final del siglo xviıI, el acceso otorgado a misioneros en continua confrontación con los militares sobre el control de los indios provocó intensos problemas entre las autoridades civiles, militares y eclesiásticas. Las diferencias se sustentaban en las "vías” más efectivas para controlar a la masa indígena, que iban desde la reducción al amparo misional, hasta el exterminio deliberado de la masa insurrecta. Sin duda, mediaba el interés de los nuevos colonizadores por 
su "derecho" a emplear el trabajo indígena en sus haciendas ganaderas, ranchos y ocasionalmente en el servicio doméstico, emulando, tal vez, el viejo sistema de la "congrega” instaurado en el Nuevo Reino de León al suprimirse las encomiendas aún vigentes en los albores del siglo XVII. ${ }^{36}$

El 30 de enero de 1809, el mismo año en que fray Mariano presentó su proyecto a Fernando VII, el gobernador de la provincia de Texas suscribió un informe sobre el estado de las misiones existentes en su jurisdicción bajo la consigna de que los "piadosos establecimientos están hoy en día en estado bien deplorable”. Además de describir la ruina en que se encontraban las edificaciones, en particular la iglesia de las misiones de Espíritu Santo y de Nuestra Señora del Rosario, lamentaba que las misiones de la Purísima Concepción, San José, San Juan y San Francisco de la Espada, que contaban con grandes porciones de terrenos y abundancia de agua para la agricultura, se hallaran incultas por falta de indios o de pobladores "de otras clases" para que las trabajaran. Se refiere así a la intención de repoblar esas misiones tratando de atraer a los indios de las misiones del Rosario y del Refugio que se situaban en parajes sin agua para riego, que nunca habían querido mudar de residencia por encontrarse cercanos a la costa de donde eran originarios, además del miedo a los indios comanches, amigos de los españoles y enemigos de ellos. Los indios cocos, que vivían en la costa, en el desemboque del río Colorado, estarían dispuestos a mudarse

${ }^{36}$ AGOFM, M. Missioni, 32, "Noticias de las misiones de Tampico sacadas de papeles originales existentes en el archivo del Convento grande de Nuestro Padre S. Francisco de México", 1748. Véase Alcocer, Bosquejo de la bistoria. 
a las misiones de la Bahía del Espíritu Santo si a cambio la corona les pagaba su manutención. ${ }^{37}$

En el mismo expediente se da cuenta de las misiones de la provincia de Coahuila: San Juan Bautista, San Bernardo, Dulce Nombre de Jesús y San Francisco de Vizarrón, en donde vivían 245 indios de las naciones pampopas, tilijaes, borrados, pacuaches, pacoas, sixames, pausanes, cholomos, norteños y julimeños, y 302 "españoles". Los indios habían olvidado por completo sus lenguas "por el poco uso que tienen a ellas y el mucho trato y comunicación con los españoles”, y sus misioneros, además de los 450 pesos de sínodos que recibía cada misión, estaban solicitando apoyo militar y económico para ir a buscar naciones de indios a la costa e integrarlos a las misiones de Coahuila y Texas que se encontraban escasas de indios. ${ }^{38}$

Luego de dos siglos de intentos por reducir a los indios al orden español, la corona parecía darse por vencida en la batalla contra la infidelidad en esa región. Se confiesa incapaz de controlar a los nativos por la vía de las armas, al mismo tiempo que reconoce la destreza guerrera de los grupos nativos sobrevivientes a la conquista y a la colonización. Tras décadas de enfrentamientos, se sabe que el número de

37 Weber, La frontera norte, p. 94, asegura que en la década de 1820 las misiones de Texas acogían a pocos indios por lo que los misioneros del Colegio de Zacatecas no veían razón alguna para permanecer en ellas: "esas misiones se aferraban tan precariamente a la vida que cuando en ese mismo decenio crecieron las presiones para secularizarlas, sucumbieron con facilidad".

38 AGI, Audiencia México, leg. 2736, "Expediente de misiones relativas a Querétaro, cuentas y listas de misioneros, peticiones al virrey pidiendo nuevos religiosos, informe sobre el estado de las misiones, por ejemplo las misiones de Taraumara y sus gentiles", 1805-1809. 
grupos nativos ha mermado en gran cantidad, pero no se ha acabado con ellos. ${ }^{39}$

El proyecto de transformarlos por la vía pacífica resuelta así un absoluto fracaso, y a las misiones se les aprecia como espacios de refugio en donde se fortalecen y reorganizan para atacar pueblos y villas y cometer actos de apostasía. ${ }^{40} \mathrm{El}$ decaimiento de la labor misionera, aunado a lo que podría parecer el último intento de una larga y costosa conquista espiritual, sin duda estaba presente en el pensamiento de fray Mariano. Las dificultades lingüísticas, sumadas a la carencia de misioneros jóvenes disponibles o dispuestos a trasladarse a esas provincias, que le parecían infestadas de indios insumisos y apóstatas, enemigos del rey y de conocida y rancia barbaridad, le llevaron a idear un método más práctico y accesible a la realidad política y financiera de la Nueva España: separar a los niños del medio en el que habían nacido para transformarlos en misioneros. A diferencia de los métodos de conversión aplicados en las misiones franciscanas en el noreste, en los que los indios eran reducidos en grupos formados por niños y adultos dentro de una misión cerrada con altas tapias, en donde recibían la doctrina y trabajaban en los obrajes, las huertas y, en el exterior, en la siembra y la cosecha, y el cuidado del ganado, fray Mariano trabajaría únicamente con los niños de infieles que se formarían en un ambiente controlado, lejos de sus con-

39 A lo largo de los siglos xvir y xviII, surgieron en el noreste diversas políticas para "castigar" a los indios insumisos. Unas más definitivas que otras, pero sin duda, estas políticas buscaron acabar con los indios: véase VENEGAS Y VALDÉs, La ruta del horror.

${ }^{40}$ Sheridan, Anónimos y desterrados, pp. 346-347. 
géneres y de un entorno de barbarie, infidelidad y apostasía que pudiera malograr el proceso de formación. ${ }^{41}$

El método propuesto por el dieguino formaba parte de una política de conversión de larga data aplicada en Asia por la Sociedad de las Misiones Extranjeras de París, ${ }^{42}$ de la que formaba parte el padre Claudio Francisco Letondal, a quien fray Mariano apoyó en su estadía en la capital novohispana entre 1803 y 1804, en donde se dedicó a promover la urgente necesidad de renovar el trabajo misionero en Asia. Letondal escribió un librillo que, en 1804, fue entregado por influencia de fray Mariano a la Suprema Real Junta Central por mano de don Manuel Jáuregui, cuando éste pasó a Nueva España como comisionado de la Junta de Sevilla. En la Relación de las tribulaciones de los fieles, el padre Letondal describe los principios del método de evangelización en Asia que habían sido aplicados con éxito, como la integración de los niños de padres infieles a partir de que han sido bautizados, para "formar una Clerecía de Individuos Naturales de los Países de idólatras [...] un Clero, que si está bien forma-

${ }^{41}$ Patios, huertas, corrales, casas de los indios, convento o casas de los frailes, así como la iglesia, el obraje y la troje, formaban el asentamiento fijo de la misión, el cual estaba rodeado de muros de más de dos varas de altura con un acceso controlado, con puertas dobles o sencillas con llave, dominando así a los indios, reducidos "con fuerza y poder convenientes", como se describe en el inventario de la misión de San Francisco de Vizarrón de 1679, asentada en la provincia de Coahuila. SHERIDAN, Anónimos y desterrados, p. 183.

${ }^{42}$ La Sociedad de las Misiones Extranjeras de París se creó en Roma entre los años 1658-1663 por medio de la Congregación para la Evangelización de los Pueblos como una institución misionera formada por seculares y laicos, quienes trabajaban en países extranjeros, principalmente asiáticos, bajo el principio de adaptación a las costumbres y formación de un clero nativo. 
do, tendrá, además de otras, la ventaja de no acabarse [...] y de hablar mejor la lengua". ${ }^{43}$

Fray Mariano hace especial referencia al martirio de Pedro Ly, misionero "nacional" en Corea, quien, asegura, "en poco tiempo hizo un rebaño de cuatro mil católicos y de estos varios padecieron martirio el año de 1791", además de asegurar la formación de más de 100 misioneros nacionales chinos formados en colegios europeos (Francia, Nápoles, Roma) y de más de 200 "colegiales", aun cuando la revolución francesa puso en aprietos la constancia en la formación de estos niños asiáticos. Fray Mariano descubre en Letondal "lo fácil que es en aquellos Reynos [Asia] la conversión de los gentiles por medio de Catequistas y Misioneros Nacionales, y cómo con poco dinero se pueden mantener", al mismo tiempo que denuncia el riesgo de falta de manutención de los misioneros como causa inminente del fin de la religión católica en aquellos dilatados imperios.

A partir de las descripciones de Letondal, fray Mariano estructuró la creación del Colegio hasta el último detalle, a sabiendas de que la formación de una clerecía de naturales para misionar en China había logrado cierto éxito y le resultaba absolutamente factible para aplicarse en América.

43 Letondal, Relación de las tribulaciones. Palau y Dulcet, Manual del librero hispanoamericano, p. 76, incluso, asegura que "aunque la dedicatoria la firma Claudio Francisco Letondal, el autor es fray Mariano López y Pimentel”. La referencia es mencionada también por Morales, "De la utopía a la locura", p. 80, como una carta enviada por Letondal a fray José Muñoz, misionero en China y exrector de la universidad de Manila, fechada el 21 de mayo de 1804. La práctica de fundar colegios para formar misioneros indígenas fue también aplicada por los jesuitas en la India y en China: véase Ponce Alcocer, Cartas desde India y China. 
Entre la información a la que debió tener acceso el fraile dieguino, dados los argumentos que emplea en su justificación, es muy probable que haya accedido al proyecto del franciscano del Colegio de Guadalupe de Zacatecas, fray José Alberola, lego de 35 años nacido en Valencia, España. ${ }^{44}$ Este fraile, en respuesta al llamado del gobierno peninsular, que buscaba nuevos proyectos para resolver viejos problemas, como el de los indios insumisos en el norte de Nueva España, en febrero de 1800, por vía del ministro de Estado, el Conde del Valle de Orizaba, envió al rey un plan con el que, aseguraba, se podría lograr la civilización de los indios bárbaros habitantes de las Provincias Internas, cuyo fundamento era atraerlos con "dulzura al Gremio de Nuestra Santa Fe Católica y al gobierno de la vida civil”. ${ }^{45}$

A diferencia del proyecto de fray Mariano López y Pimentel, el de Alberola es un plan más simple en cuanto a las estrategias elegidas para lograr la conversión de los nativos, equiparables a las empleadas tradicionalmente por los misioneros franciscanos, pero más ambicioso en tanto que se proponía la conversión con los atributos y características

${ }^{44}$ Existen escasas referencias a este proyecto y a los datos biográficos del fraile Alberola, excepto por los relacionados en los dictámenes sobre su proyecto.

${ }^{45}$ AGI, Estado, 29, núm. 19, 21 de julio de 1801, "Reservado. Testimonio del expediente construido en virtud de Real Orden para que se examine el proyecto del Padre Misionero del Colegio de Guadalupe de Zacatecas sobre civilización de los Yndios Bárbaros". A partir de este momento todas las referencias al proyecto de Alberola derivan de este documento. Otro escrito relacionado es: AGI, Estado, 41, núm. 42, 16 de febrero de 1800, "José Alberola proponiendo plan para la reducción de indios". 
económicas de las empresas de conquista, ambición que le costó la sanción negativa del virrey Félix Berenguer de Marquina.

Pero a diferencia de los métodos misioneros de los franciscanos, que se explican desde la imagen del "son de campana", es decir, la reducción de los indios dentro de una misión que se caracterizaba por ser un espacio cerrado y perfectamente controlado, el fraile Alberola se proponía la conversión desde la tradición más clásica representada en la noción pure espiritual o pureza evangélica, ${ }^{46}$ viviendo entre los indios "para franquearles con especialidad y seguridad nuestra amistad", eximiéndose de la injerencia de autoridades civiles, militares y aun eclesiásticas, $y$ ofreciendo a cambio un importante ahorro al erario en materia de defensa presidial:

La falta de Política, inteligencia y conocimiento en esta parte, son causa, en mi concepto, de nuestros atrasos; pues vemos claramente que los Yndios en lugar de rendirse a nuestras armas, cada día se imposibilita más su reducción; por lo que

\footnotetext{
${ }^{46}$ Pure o pureza espiritual, identificada con los primeros tiempos de los frailes franciscanos observantes y posteriormente los espirituales que en el siglo Xvi eran reputados por alentar la oración mental, contemplación, estados místicos. Pérez, Teresa de Ávila, "una espiritualidad más orientada a la sensibilidad que a la razón", encausada al retorno de la Iglesia primitiva o a la renovación de la Iglesia. Fray Martín de Valencia, quien guiaría a los 12 apóstoles a la conquista espiritual de la Nueva España (1524), representaba esta necesidad respaldada por la bula del papa León X, en la que a los misioneros se les otorgaba absoluta licencia para predicar sin tener que atender a ninguna autoridad eclesiástica o civil en la forma de llevar a cabo sus acciones. Castro y Rodríguez, Bernardino de Sahagún, p. 185, suman a ésta la bula del papa Adriano VI, firmada en España en 1522, en la que se les reconoce "toda autoridad plena del Sumo Pontífice, tanta cuanta a ellos les pareciere ser conveniente para la conversión de los indios".
} 
ya es preciso abrir los ojos; y tomar un método diametralmente opuesto al que hemos seguido hasta ahora [... para esta evolución Exmo. Señor, no ha de haver más armas que la amorosa palabra de Jesús Cristo, y por consiguiente sus efectos.

En un claro embate contra las fuerzas militares, Alberola calificaba los presidios como "guarniciones inútiles”, argumento con el que orientó su estrategia a uno de los puntos más débiles de la política española sobre esa región: la colonización y consolidación de los asentamientos logrados. Se propuso la transformación de los presidios en "haciendas útiles” favoreciendo la secularización del espacio al "abolir enteramente todo lo que huela a militar”, con lo que intentaba asegurar el "buen trato" hacia los indios "con el fin de que en lugar del horror que nos tienen, sobstituyan [sic] la amistad y buen afecto por su propio interés y comodidad". Se crearían nuevas misiones, además de eliminar las que ya no parecieran ser "útiles", para crear más adelante haciendas y ranchos productivos poblados por los indios ganados y colonos de "diversas castas" que él se comprometía a proporcionar. Prometía además la fundación de pueblos que con el tiempo darían pie a algún comercio.

El proyecto daría resultados antes de diez años si el gobierno garantizaba los auxilios en dinero y efectos "sin escasez", por vía del virrey, entre los que consideraba los fondos piadosos de misiones de los que se le deberían señalar 4000 pesos anuales y otros 2000, "para llevar un hombre Decente [acompañante] y un Escribiente”.

En el proceso de revisión sobre la viabilidad de la empresa, el fraile hizo algunas modificaciones al plan, consistentes, principalmente, en inflar los costos de la empresa 
comparando su proyecto con el fondo piadoso de las Californias, que había recibido más de 500000 pesos. Otra adenda a la representación original trataba de una concesión personal para el ejercicio del libre comercio por 10 años tierra adentro, "echando una línea divisoria por las fronteras", desde Sonora vieja y Nueva California, Chihuahua, Nuevo México y Paso del Norte; Durango y Sombrerete, Texas y Coahuila, Saltillo, las colonias de Santander, Río Verde, "y sacar desde la expresada línea para tierra afuera, libre de Alcabalas bajo el mando de un comisionado".

En mayo de 1802 el virrey Marquina remitió a la corona los resultados de las pesquisas realizadas por su gobierno en relación con el plan de Alberola:

[...] se me previno que en caso de considerar asequible lo propuesto por el P. Alberola, auxiliase sus ideas franqueándole lo que pidiera [...] y allanar primero con la persuasión y la virtud de la predicación la grave dificultad de poblar en tierras de infieles o en sus fronteras.

Para ello solicitó informes al intendente de Zacatecas y al padre guardián y discretorio del Colegio Apostólico de Nuestra Señora de Guadalupe de Zacatecas, de donde se derivaron una serie de juicios que descalificarían el proyecto de fray José Alberola de manera definitiva.

El inconveniente que destaca como más relevante es el de comprobar que el fraile resultó de profesión lego, con nueve años de haber tomado el hábito. Previamente había servido como sargento en uno de los regimientos de veteranos: "su virtud no es especial [...] su instrucción es ninguna, de que se sigue que sus representaciones estén llenas de 
inconsecuencias, falsedades y contradicciones”. Este hecho, aunado a la documentación que le fue solicitada con posteridad a la primera representación, en la que aseguraba que el plan se llevaría a cabo sin gasto para el erario, y que posteriormente inflaría los costos, llevó a la conclusión de que el proponente estaba incapacitado para desarrollar un plan de tal magnitud, ideado como una empresa personal:

La mayor prueba de la falta de capacidad y conocimiento del hermano Alberola, aun en la observancia de las reglas de su profesión, es el que siendo fraile de San Francisco, piense como lícito comerciar sin paga los Reales derechos; mandar a los sacerdotes, poseer cuantiosos sueldos como los que pidió; gobernar tropas, premiar, castigar, tener a todos pendientes de su voz, y los demás despropósitos que advirtieron oportunamente los Fiscales de Real Hacienda y Protector de Naturales.

Al cuestionársele sobre el método de evangelización que sustentaba su proyecto, la argumentación esgrimida por el fraile demostraba que, a diferencia de fray Mariano López Pimentel, tenía un amplio conocimiento sobre hechos específicos y recientes de la vida misional en el norte como, por ejemplo, detalles sobre acuerdos entre el gobierno español y los indios comanches o bien, el estado de la guerra con otras naciones enemigas como la entablada por la corona contra los indios lipanes.

A la manera de un poblador o un pacificador, más que a la de un misionero, el fraile propuso la conversión in situ en una de las regiones de mayor cuidado y debilidad para la corona, por lo que su proyecto fue duramente cuestionado, ya que parecía que estaba dirigido a "hacerse dueño de 
aquellas reducciones", tanto en la potestad temporal como espiritual. En el dictamen final se aseguraba que la idea de pacificar las Provincias Internas por medio de poblaciones era un "pensamiento muy antiguo", y sí, efectivamente podemos rastrearlo desde los primeros esfuerzos misioneros y hasta la secularización final de las misiones en Texas. ${ }^{47}$

\section{EL PROYECTO DE FRAY MARIANO LÓPEZ Y PIMENTEL}

Las diferencias entre los proyectos de ambos frailes no se reducen sólo al método de conversión sino, de manera relevante, a la materia de trabajo que cada uno presumió, o imaginó, y que daba sentido a su propuesta. En el plan de Alberola se mencionan tres o cuatro denominaciones de indios que define como "insumisos", es decir, grupos indígenas que aún se mantenían adversos a la corona y que podían ser clasificados tanto como "amigos" o como "enemigos"; mientras que fray Mariano imagina el impacto de su propuesta sobre la infidelidad global, compuesta por una masa de millones de almas en riesgo de perderse en el infierno, que coloca en América y Asia, principalmente en China. ${ }^{48}$

\footnotetext{
47 Véase SHeridan, Anónimos y desterrados.

48 Existe una amplia bibliografía sobre los procesos de colonización, misionización y control de los espacios indígenas en el nororiente y noroccidente de la Nueva España, que difieren en muchos aspectos, tanto por la influencia jesuita y franciscana, como por la diversidad cultural y las formas de confrontar a los indios considerados "enemigos" de la corona. Al respecto véase DeEds, Defiance and Deference; Cramaussel, La provincia de Santa Bárbara; RAdDIng, Wandering Peoples; SHERIDAN, Anónimos y desterrados; SHERIDAN y NAYLOR, Raramuri; SHERIDAN y Parezo, Paths of Life; Weber, Bárbaros, entre otros.
} 
Más que una crítica de fondo a la actividad misionera en el norte de la Nueva España o a la influencia negativa de los militares en el proceso de evangelización que tanto enfatizó el fraile Alberola, para fray Mariano la traba más importante en el proceso de evangelización en América y China radicaba en la comunicación: el punto de distancia y posible acercamiento a la fe era la lengua. La "desconfianza", como principio de una comunicación fallida, ya había sido mencionada por fray José Alberola, aunque éste la coloca en un contexto de confrontación entre las fuerzas militares y el trabajo misionero como causa de la dispersión de los indios, mientras que fray Mariano atiende a la diversidad cultural y las muchas lenguas de los indios, asociadas a la dificultad de los misioneros para aprenderlas todas.

Fray Isidro Félix de Espinosa" hacía referencia a "tanta diversidad de idiomas, pues hay misión donde se hallan seis diferentes lenguas".$^{50}$ Igualmente, fray José Antonio Alcocer, cronista del Colegio de Nuestra Señora de Guadalupe, aseguraba que en cada una de las misiones de Texas "aunque tenga muy pocos indios tiene diversos idiomas, y aún son más los idiomas que las naciones, a causa de que las existentes conservan el idioma de las que han faltado y usan del propio" ${ }^{51} \mathrm{La}$ diversidad lingüística provocó incluso que

${ }^{49}$ Misionero franciscano formado en el Colegio de la Santa Cruz de Querétaro, asignado en 1709 a la misión de San Juan Bautista, y posteriormente nombrado presidente de las misiones de Texas, fue también cronista de la provincia de Michoacán y entre sus obras destaca su Chronica Apostólica y Seráfica de todos los colegios de Propaganda Fide de esta Nueva España.

50 Espinosa, Chronica Apostólica y Seraphica, p. 771.

51 Alcocer, Bosquejo, p. 180. 
algunas de las misiones tuvieran que dividirse en dos o más establecimientos, ya que era imposible mantener en paz en una misma misión a nativos que hablaban diversas lenguas porque en libertad eran enemigos territoriales, corroborando así que los indios guardaban entre sí enormes diferencias culturales y territoriales asociadas a su pertenencia lingüística. ${ }^{52}$ Fray Mariano conocía sin duda las dificultades asociadas a la diversidad de naciones que vivían en las Provincias Internas, mismas que se manifiestan en el informe del virrey Conde de Revillagigedo que el fraile aseguró haber consultado, por lo que, en gran medida, su proyecto se asienta en el reconocimiento de una clara diferenciación cultural sustentada en la lengua.

Sin embargo, en el pensamiento del fraile también se observan influencias importantes de los franciscanos de los primeros tiempos de la evangelización, "nuestros mayores", específicamente de fray Gerónimo de Mendieta en relación con el valor de las lenguas indígenas en la enseñanza de las verdades evangélicas, así como con la práctica litúrgica por medio de los catecismos y confesionarios puestos en la lengua nativa de los gentiles. Probablemente también en relación con la importancia de la lengua puesta en la inocencia de los niños indígenas, como herramienta fundamental de

${ }^{52}$ Desde el establecimiento de los primeros asentamientos en Saltillo y Parras, en la Nueva Vizcaya, se hacía referencia a la diversidad de lenguas asociada a las dificultades para definir los asentamientos indígenas, como se menciona en las mercedes de tierras otorgadas a los frailes franciscanos y a los tlaxcaltecas entre indios huachichiles y rayados: "por estar como está esta dicha Villa [Saltillo], en frontera por una parte de indios huachichiles, y por otra, indios rayados de diferentes lenguas, y los dichos indios huachichiles tener [...] guerra con los dichos indios rayados, y cada día flecharse y matarse": SHERIDAn, Anónimos y desterrados, p. 102. 
la evangelización que, para Mendieta, resultaba una fórmula preciosa para superar las falsas conversiones y los constantes retornos a las idolatrías:

Era esta doctrina de muy poco fruto, pues ni los indios entendían lo que se decía en latín, ni cesaban sus idolatrías, ni podían los frailes reprendérselas, ni poner los medios que convenía para quitárselas, por no saber su lengua. [...] Y púsoles el Señor en corazón que con los niños que tenían por discípulos se volviesen también niños como ellos para participar de su lengua, $\mathrm{y}$ con ella obrar la conversión de aquella gente párvula en sinceridad y simplicidad de niños. [...] Porque niños fueron los maestros de los evangelizadores. Los niños fueron también predicadores, y los niños ministros de la destrucción de la idolatría. ${ }^{53}$

Es importante subrayar que, más que procurar la castellanización de los indios, los frailes menores se empeñaron en aprender sus lenguas, pese a la oposición de la administración colonial, ${ }^{54}$ principios a los que, evidentemente, se adhirió el proyecto de fray Mariano y que, paradójicamente, formarían parte de la descalificación del mismo frente a las autoridades eclesiásticas, como se menciona en el dictamen más adelante.

En ese sentido, es posible asegurar que la columna vertebral del proyecto, la formación de "Misioneros Nacionales para convertir y catequizar a los Ynfieles de la Asia y Améri-

53 Mendieta, Historia eclesiástica, pp. 117-119.

54 Domínguez Reboiras, "El 'cuidado y curiosidad”", p. 322, anota que "los frailes menores buscaban sobre todo la no hispanización de los indios [...]. Se ha llegado a afirmar que para la mayoría de los frailes menores del siglo XVI ‘cristianización’ e ‘hispanización’ eran dos términos opuestos y recíprocamente excluyentes”. 
ca, hablándoles en sus nativas lenguas", las cuales, por cierto, le parecían "casi incomprensibles", se sustentaba en los principios franciscanos más tradicionales. Sin duda, la influencia de fray Gerónimo de Mendieta se aprecia ampliamente en la manufactura del plan, sobre todo en su idea de una comunidad indígena estructurada, como apunta Florescano, en torno de un "gran monasterio o una gran escuela" 55 y el valor que Mendieta otorgó a la formación de los niños.

Los niños gentiles asistirían al seminario para aprender el Evangelio y sus preceptos, además de los métodos de catequización que aplicarían a sus "connacionales" 56 en ambas lenguas, la propia y el castellano, con lo que se crearía en el tiempo "una nueva Clerecía de Misioneros Nacionales que les hablen al alma en sus propias lenguas para catequizarlos, civilizarlos y reducirlos a Pueblos y al gremio de la Santa Yglesia". Es por ello que no duda en llamarlo "Colegio de lenguas".

En relación con el método pedagógico propuesto por fray Mariano, es conveniente ubicar su propuesta en un contexto de divergencias de larga data respecto a la ordenación de jóvenes nativos como misioneros, en donde, desde el siglo xvi, la calidad de neófito (recién convertido) era tal vez la traba más expuesta en las réplicas a la ordenación de indígenas. ${ }^{57} \mathrm{La}$ materia de trabajo del fraile era "todo el gentilismo", es decir, una masa de paganos e infieles que habitaban en "las cuatro partes del mundo", que sólo en China y "estas

55 Florescano, Memoria mexicana, p. 286.

56 El término “connacionales” es empleado por López y Pimentel seguramente en relación con el uso del sustantivo "nación” para definir la adscripción de los nativos, mismo que se empleaba desde los inicios de la conquista espiritual.

57 Al respecto véase Duve, “Derecho canónico y la alteridad”. 
provincias internas" sumaban 660000000 , entre los que aseguraba que 26000000 morían anualmente en pecado "porque no hay quien les predique en su idioma".

El fraile apostaba a la redención de esos millones de almas en 12 niños de cada nación -de entre 7 y 8 años de edad-, que ingresarían al Colegio anualmente acompañados por uno o dos indios grandes que hubieran servido de intérpretes en las misiones y que fungirían como maestros de lenguas. Los intérpretes vivirían con los niños en sus "departamentos" para "que hablen entre sí su idioma nativo, para que de esta suerte no lo olviden, ínterin aprenden el nuestro". Se proponía un sistema de congregación en un espacio estructurado bajo la disciplina de la reducción característica de las misiones franciscanas en el norte de la Nueva España, a "son de campana”, en el que el tiempo se organizaba y ordenaba jerárquicamente en relación con el aprendizaje de la doctrina y de las artes y oficios, como complemento indispensable para alcanzar la civilidad:

[...] se les darán diariamente tres horas de instrucciones y ejercicios espirituales, repartidos entre el día y la noche. Tendrán tres horas de estudio: tres de escuela y clases: tres de labor y ejercicio corporal en los oficios y artes, para que los aprendan y se ayuden a vestir y mantener: dos horas de recreación y diversión en sus huertas y jardines en donde aprendan también a cultivar la tierra, y á tocar sus instrumentos músicos para atraer a los indios: dos horas para el alimento, que lo tomarán siempre acompañado de buenas lecciones espirituales: y ocho horas de descanso y sueño [...] entretenidos y bien ocupados aprovecharán, estarán contentos y saldrán doctos y santos, capaces de convertir a todo el gentilismo. 
La elección de definir el número de 12 niños, que evidentemente refiere a los 12 franciscanos que llegaron a América bajo la guía de fray Martín de Valencia en 1524, parece mostrar una especie de retorno a la autoridad apostólica concedida en 1522 por Adriano VI en su bula Exponinobis fecisti, expresada con vehemencia en la crónica de Alonso de la Rea:

Gobernando la Iglesia feliz y dichosamente Adriano Sexto, e imperando glorioso nuestro Carlos Quinto en España, llegaron a las Indias Occidentales, aquellos doce varones en el número y en la santidad apóstoles de este Nuevo Mundo, y soles tan resplandecientes que, deshaciendo las nieblas de la gentilidad, alumbraron y destruyeron el engaño de sus errores. ${ }^{58}$

Tal vez por eso es posible apreciar la influencia de la racionalidad luliana (Ramón Llull, 1232-1315) sobre el espiritualismo franciscano global, o "plan de comunidad universal”, que encuentra Escandell en la creación de los colegios de formación misionera "como centros preparatorios de la eficacia de la propia acción apostólica”, aplicado por primera vez en la evangelización de las Canarias en el siglo Xvi. ${ }^{59}$ Parece posible afirmar entonces que fray Mariano intentaba volver a ese principio de los misioneros espiritualistas en el que la noción de "infiel” define al sujeto de transformación.

${ }^{58}$ Escandón, Crónica de Alonso de la Rea, p. 95. La referencia al número 12 se sustenta en "la primitiva iglesia de Dios", sus 12 apóstoles, que sería reinaugurada en la Iglesia de América, como lo afirma PAstor, El jardín y el peregrino: "en esa figura se resuelven simbólicamente las contradicciones históricas que enfrentaban desde la Edad Media en oposición irreconciliable a la Iglesia de Roma con los ideales primitivos cristianos [...] el orden simbólico de la progresión hacia la utopía”, p. 193.

${ }^{59}$ Escandell, Teoría del discurso historiográfico, pp. 269 y 278. 
La colonización española solo adquiere sentido por la cristianización de los indios infieles:

[...] se congregará en este Colegio una porción de niños, hijos de los mismos infieles, para educarlos bien en la fe, enseñándoles los principios y fundamentos de la religión católica, las virtudes y ciencias de los santos, y las artes y oficios que pueden necesitar para civilizar, enseñar, catequizar y convertir a los infieles de la Asia y América; y que con estas habilidades y gracias puedan internarse en las más remotas regiones de la China y de las provincias internas, y así puedan reducir a pueblos los indios bárbaros y gentiles que habitan en ellas.

En cuanto a la materialización del proyecto, fray Mariano propone la edificación de una monumental obra arquitectónica diseñada por el escultor valenciano Manuel Tolsá (1757-1816) -“el adjunto Mapa formado por D. Manuel Tolsá”-. El diseño arquitectónico es un ejemplo indiscutible de la arquitectura ilustrada a la que hace referencia W. Rey Ashfield. Los planos conforman un edificio de base rectangular en el que se cuentan un centenar de habitaciones de todos tamaños, y más de 20 patios para proveer de luz solar y ventilación a las diferentes áreas de departamentos, escuelas, refectorios, etc., que remarcan la base higienista característica de esta arquitectura y que, a la vez, es expresión de una "idea utópica de un edificio-ciudad autónomo, autosuficiente e incontaminado" cargado de una "vocación ordenadora fuertemente geométrica $[. .$.$] al tiempo que una$ considerable desmesura". ${ }^{60}$

60 Ashfiled, “Arquitectura ilustrada”, pp. 59 y 66, analiza el proyecto de una Casa de Misericordia en Montevideo diseñada por el arquitecto 
El trazado arquitectónico interior contempla la construcción de 20 departamentos, uno por cada grupo nativo, los cuales contarían con servicios, dormitorios, patio, oficinas, etc., "para que estén con separación los niños de cada nación, y no se confundan en sus idiomas con la continua comunicación; y cuando se juntaren en los patios comunes de las escuelas, ciencias y artes, hablarán en castellano, que es lo primero que deben aprender, para enseñarles con facilidad y sin trabajo todo lo que deben saber".

Los departamentos se localizan en la mitad norte del plano del Colegio, a cada lado de la estructura central o común, definidos como "Departamentos de Chinos" y "Departamentos de Yndios". En los primeros coloca en un lugar específico las adscripciones étnicas asiáticas que se propone integrar: japoneses, tártaros, cochinchinos, sutenchenes, jonguinos, mogoles, tiberinos, coreanos, manilos y chinos. Lo mismo hace con los departamentos de indios: texas, tarascos, otomís, gilas, californios, guichitas, tanguayas, patagonios, pampas, tancagues, comanches, lipanes, apaches y mexicanos. Los grupos asignados a los departamentos de indios seguramente responden a la intención de incluir a todos los infieles de las Américas, pues aun cuando en la elección se aprecia una clara preferencia por la reducción de los indios habitantes de las Provincias Internas de Nueva España, como lipanes, apaches, comanches, californios, gilas, guichitas, texas, tanguayas y tancahues, no deja de sorprender la inclusión

Tomás Toribio, contemporáneo de Tolsá, que compara con el proyecto del Colegio de Misioneros, que resultan coincidentes por "el uso de modelos edilicios asociados a ideas de base higienista", destacando el segundo por sus "fuertes tintes utópicos y acentos megalomaníacos". 
de patagonios y pampas, grupos nativos de la frontera indígena al sur del virreinato del Río de la Plata, ${ }^{61}$ y tarascos y otomíes, dos grupos con los que trabajó estrechamente fray Diego Valadés en el siglo xvi. ${ }^{62}$

La traza dentro del plano separa y a la vez une a los congregados: una línea o eje central divide el edificio completo desde la entrada en la que se localizaría la iglesia capaz de contener 2000 personas. Tras la iglesia mayor se encuentra la capilla con bautisterio, la cual, en su parte trasera, conectaría con el patio central que en el plano reza "las Artes y oficios se colocan en estos claustros y patio el cual sirve también de patio de deshago y juegos". Hacia el norte, dividiendo las áreas de departamentos, se ubicaría un patio "general" rodeado de refectorios y cocinas y un patio más rodeado de bodegas y almacenes de granos y semillas. A los lados de la iglesia, las aulas, patios diversos, escuelas, oficinas y una imprenta destinada a la impresión de catecismos en las lenguas nativas de los niños congregados.

Aun cuando el fraile parte de la presencia de distintas lenguas nativas de Asia y América y, por tanto, de la necesidad de ubicar a los indios y a los asiáticos en departamen-

${ }^{61}$ John, “The Multilingual”, p. 156, confunde la inclusión de pampas y patagonios en un intento por colocar adscripciones lingüísticas a los indios mencionados en el plano, y asegura que estos dos grupos son hablantes de lengua coahuilteca y que vivieron en las misiones de San Antonio (Texas) y las del norte de la provincia de Coahuila. En la extensa relación que realicé sobre nombres de grupos indígenas en el norte de Nueva España, basada en documentos originales de diversos archivos en México, Estados Unidos y Europa, no aparece mención alguna sobre estos grupos como habitantes del área de Texas y Coahuila. Véase SHERIDAN, Fronterización.

62 Véase Palomera, Fray Diego Valadés, OFM. 
tos separados, no descuida la diferencia cultural entre indios y chinos. A lo largo del documento se encuentran referencias a la idea de barbarie ligada a los indios habitantes de las Provincias Internas: les adjudica una serie de características negativas que solían emplearse en la documentación colonial para definir a los indios nómadas infieles, también denominados idólatras, paganos y gentiles, como que

[...] son infatigables en el trabajo de correr por los montes y sierras $[\ldots]$ no extrañarán sus climas y temperamentos, ni los alimentos silvestres asquerosos y groseros de los gentiles: saben bien sus guaridas, usos, abusos y costumbres. La Religión dominante entre estas naciones es la idolatría, y todos estos gentiles, idólatras y paganos son esclavos del demonio y se condenan.

Probablemente en referencia explícita a la bula Veritas Ipsa, en la que se reconoce y reivindica la racionalidad de los indios y su capacidad para aceptar la fe, ${ }^{63}$ defiende la calidad humana de los nativos del norte y critica enérgicamente a quienes dudaron de su condición no animal. El dieguino supone que el error original del fracaso de las misiones establecidas entre los nativos de las Provincias Internas fue haber considerado a los indios seres irracionales; le parecía que "'antes por el contrario, mucha malicia, viveza y comprensión' tanta que escuchando sus confesiones, ha observado que a pesar de ser rústicos y de muy mala vida, un teólogo no se explicaría mejor y con tanta claridad". ${ }^{64}$ Mien-

${ }^{63}$ Respecto a la bula Veritas Ipsa, véase Carrillo Cázares, El debate sobre la Guerra Chichimeca, p. 101.

${ }^{64}$ Citado por Morales, "De la utopía a la locura", p. 80. 
tras que en relación con los chinos no cuestiona sus costumbres ni se afana en buscar las vías más apropiadas para influenciarlos y llevarlos a la "civilización”, aun así, indios y chinos, son para el fraile "los hijos de Adán” que vagan “en las tinieblas y horrores de la infidelidad" y "todos son hijos de un padre que está en los cielos”.

Los bárbaros del proyecto del fraile son los indios, los chinos son meramente infieles. Esta diferencia parece ser sustantiva en la definición de la instrucción para unos y otros: los niños de "Nuevo México, California y Provincias del Norte”, serían instruidos en gramática, filosofía, teología y moral, sin desatender la aplicación a las artes mecánicas y liberales; mientras que a los de China, que no necesitarían aprender de oficios porque los considera hábiles en ellos, se les enseñarían las matemáticas y la astronomía, “pues esto les ayuda mucho en sus reinos para introducirse con los Reyes”. Las materias que serían compartidas por todos niños, sin distinción de raza, serían las de medicina y cirugía, a las que define como "oficios de caridad" que les ayudarían a atraer "las voluntades de los infieles", ya que podrían socorrerlos en sus enfermedades y "hacerse apetecibles".

En el caso de los indios, los maestros o tutores de cada nación congregada enseñarían el castellano y su traducción a la lengua de los indios, con la intención de que éstos identificaran los términos más adecuados para impartir la doctrina, apoyados por catecismos que se escribirían en la lengua originaria y que serían impresos en el mismo Colegio. Los maestros chinos, por su parte, deberían orientar sus trabajos a la instrucción de ceremonias y política china, “con los demás usos y costumbres de aquel país”, para que no fueran tenidos por extranjeros al volver a China. 
En su empeño por mantener la cultura original de los futuros misioneros, se refiere a la indumentaria como un factor más de las diferencias que establece entre indios y chinos. Los indios deberían vestir de acuerdo con "sus naciones": "los de las Provincias Internas, usarán su camisa de manta, calzones y cotón de bayeta o paño, su sombrero y unos guaraches o sandalias de cuero". Pareciera colocar su preocupación sobre la vestimenta en la certeza de que los indios no reducidos en el norte solían andar desnudos o cubrirse apenas con alguna gamuza; de ahí la necesidad de uniformarlos con la vestimenta más común empleada entre indígenas del centro de México. En contraste, para los niños chinos no hace recomendación alguna en relación con la vestimenta. La alimentación es otro aspecto que muestra un tratamiento diferenciado: en el caso de los nativos de las Provincias Internas que, según el fraile, se alimentan de "alimentos silvestres, asquerosos y groseros", sugiere alimentos comúnmente consumidos en el centro y sur de México a base de chile, maíz y frijol, mientras que para los niños de Asia la dieta sería principalmente arroz.

El plan es profusamente minucioso. Atiende detalles de estructura y empleo, organización docente, cuidado de los niños, recreación, celebraciones de las fiestas religiosas, costos anualizados del mantenimiento del colegio, entre otras cuestiones. Destaca, por ser la materia principalísima de su proyecto, su idea de cómo trasladar a los niños al Colegio desde sus lugares de origen: en uno de los cuadernillos anota que los procuradores deberán traer a los niños con el mayor cuidado, mientras que en otro manuscrito detalla la forma de traerlos.

En el caso de los niños provenientes de las Provincias Internas, "hijos de los infieles", asegura que traerlos no 
representaría gasto alguno para la Real Hacienda, ya que los soldados los traerían cada año junto con los “indios mecos grandes que traen en collera y partidas para Veracruz y para La Habana, por bravos y perjudiciales y que andan matando a los españoles y por sus delitos los cogen y prenden”. La conducción de "los niños de la China" tampoco implicaría gastos, pues había acordado con un comerciante experimentado en el comercio con Asia trasladar a los niños en su fragata. La navegación saldría de Acapulco vía las Californias, en donde el comerciante en cuestión cargaría pieles de nutria para mercarlas en China. La fragata saldría cargada de suministros para las misiones de las Californias, además de trasladar gratuitamente a los misioneros destinados a la China y recoger a los niños hijos de infieles de las misiones. El comerciante, que favorecería la salvación de miles de almas en riesgo de perderse, además de impulsar el mercado en las Californias, se vería recompensado por las utilidades de su comercio. En caso de que el gobierno no estuviera de acuerdo con este medio, propone que la nao de Manila recoja a los niños “como vienen los pajecitos de escoba”.

Por la secuencia de los detalles descritos en el prolijo plan de fray Mariano, además de la indudable preferencia que otorga a los niños nativos de las Provincias Internas de la Nueva España, y de ellas, sin duda, a los indios rebelados a la corona, es probable que el proyecto haya sido pensado originalmente para resolver la acuciante problemática de las misiones establecidas en el noreste y que, más adelante, con el conocimiento de los escritos de Letondal, haya decidido ampliar su perspectiva hasta Asia para incluir así a todos los infieles del mundo. 
UTILIDAD DE LA EMPRESA: EL FIN DE LA INFIDELIDAD

El dieguino reconoce, y le preocupan, "los tiempos calamitosos” que en ese momento vivía España por la guerra con Francia, además de la situación interna de la Nueva España que, afirmaba, citando a Juan Crisóstomo, no superaba las malas cosechas, muerte de ganados, enfermedades y pestes, falta de reales y "otras mayores [calamidades] que pueden venirnos en castigo de nuestras culpas y pecados". Se preguntaba cómo, entonces, hacer oídos sordos de la piadosa obra del Colegio como medio eficaz para acallar la divina justicia y a millones de gentiles para formar con ellos "otros tantos templos vivos de Dios".

La obra arquitectónica propuesta, aun cuando parecía grande y costosa, no lo era porque, aseguraba, "lo más es de baxos, liso y llano" y porque planeaba su fabricación en etapas: "según lo pida la necesidad y la abundancia de los niños que vengan de varias naciones". Pero frente a las dificultades financieras de la corona, fray Mariano propuso la alternativa de un espacio adaptable a las necesidades del Colegio. Le pareció idóneo el "sitio de Chapultepec con el que llaman el Palacio de Gálvez", ${ }^{65}$ que ya se había ordenado fuera vendido por inútil a la Real Hacienda, además de la mala fama que le antecedía por haber sido empleado por el virrey Bernardo de Gálvez (1785-1787) como casa de campo para sus diversiones personales. Calculó que con 10 o 12000 pesos, el sitio podría ponerse "en conformidad" para acomodarse los primeros años y posteriormente agrandar la edificación.

65 Conocido posteriormente como Castillo de Chapultepec, en 1806 fue adquirido por el Ayuntamiento de la Ciudad de México. 
Entre las ventajas que argumentó en relación con este espacio, están la del tamaño del bosque, que ocupaba más de 2500 varas de circunferencia, su frondosidad con abundante agua, cercas y casa de campo, pero también su ubicación a una legua de la ciudad de la México, es decir, una especie de retiro o cartuja "libre del bullicio de la Corte", y a la vez accesible a las visitas de virreyes, arzobispos, canónigos y oidores que podrían visitarlo a diario y fomentar así su engrandecimiento.

Para el sostenimiento del Colegio propuso diversas vías que revelan, en general, una importante red de relaciones sociales en todo tipo de espacios. El argumento que justificaría la solicitud de fondos, lo situó como un asunto de conciencia: las calamidades por las que atravesaba España eran el reflejo de la religión, tan "relajada y alejada de la caridad de Dios”. Su proyecto mataría así dos pájaros de un tiro: por un lado se salvarían los infieles y, por el otro, se sanarían los pecados de los fieles. Por ello era enfático en el gran pecado de omisión en que incurrían los versados, miembros de las élites novohispanas a quienes solicitaba apoyo económico, legal y moral, bajo la premisa de que el proyecto había sido inspirado por Dios. El "premio" de quienes se comprometieran con el proyecto lo ofrecía inmenso:

[...] este mérito y gloria lo tendrán todos los que contribuyan con sus limosnas a la conversión de los infieles [...] para que todos se salven, y que así todos consigamos la gloria eterna [...] No me lleva pasión por los chinos y mecos pues no soy ni de una ni de otra nación. Es tiempo de hablar la verdad y de desengañar a nuestro Católico Monarca, para evitar gastos, y que todos cumplamos con la Religión y la Patria. 
Como todo financiamiento, requería de una justificación económica, calculó que las utilidades del proyecto se recogerían con el envío de los primeros misioneros a sus lugares de origen, lo cual redituaría lo mismo que "más de cien misiones vivas": por un lado, los ahorros que se generarían sobre los gastos ejercidos in situ en las misiones y presidios establecidos en las Provincias Internas, mismos que calculaba habían costado 300000000 de pesos en tres siglos; por otro lado, el valor incalculable de los beneficios que de la fundación del Colegio se desprenderían para bien de la religión y la patria.

Las "utilidades" buscaban no sólo persuadir al rey de las ventajas económicas que redundarían en favor de la corona en el mediano plazo, sino de los beneficios de largo plazo que proveería la conversión, los cuales se verían reflejados en la fundación de poblados y ciudades "en todas las Provincias Internas que están sólo pobladas de tierra y gentiles”.

Fray Mariano abreva en el imaginario de la riqueza mineral y prolijidad de las tierras de los gentiles, y asegura que ya reducidos a la fe y a la obediencia al rey, estos espacios podrían disfrutarse por sus "grandes tesoros de plata y oro". Se refiere también a lo que los proyectos de empresarios colonizadores, y del mismo Alberola, proponían como garantía en relación con la extensión de los dominios del rey, sin necesidad de guerras, tropas ni gastos asociados. Esto detendría el avance por el norte de los "angloamericanos" interesados en las mismas tierras, quienes, además, pervertían a los infieles para que "algún día nos asalten y de repente nos quiten todo lo que tenemos conquistado".

Como el plan de Alberola, el de fray Mariano parte de la seguridad de los bajos costos a cargo del real erario y se 
propone obtener donativos suficientes a partir de la invocación de la Divina Providencia como el mejor fondo y arbitrio, inagotable, asegurando que los "católicos" deseaban con el mismo fervor que él la conversión de tanto número de infieles.

Parece conocer los riesgos de una empresa tan ambiciosa al hacer referencia a la fundación de tantos conventos, colegios y hospitales en América de los que, en sus orígenes, no se confiaba el gobierno, como lo fue el convento de las capuchinas en México, que había sufrido serios reveses, entre los que subraya el dictamen negativo del arzobispo deán de la catedral, don Luis de Torres, quien calificó la idea como “imaginaria e imposible”, pese a lo cual se había llevado a cabo la fundación con una inversión de 200000 pesos, o bien, el Colegio de Minería que, para "educar a unos cuantos jóvenes", había costado al erario 1000000 de pesos.

Proponía "hacer una suscripción entre los pudientes" con lo que se podría financiar la construcción y hasta el mantenimiento del Colegio. En caso de que esta propuesta no fuera viable, se podría encomendar la obra y el establecimiento a algunas comunidades religiosas que contaran con rentas y fincas y que pudieran hacerse cargo por tener misiones en América, cumpliendo así con el precepto de misionar que les fue encomendado para venir al nuevo continente. Otra alternativa que vislumbró como fiable consistía en la recolección de limosnas en todos los curatos del reino, que le parecía serían más que suficientes y hasta sobradas; razón por la que incluyó en el plan de arbitrios a las catedrales de México, Guadalajara, Puebla y Valladolid. Pero si tampoco eso fuera posible, porque los religiosos no quisieran hacerse cargo de la empresa, podría encomendarse la obra al Real 
Tribunal de Minería, "que sería el más interesado por los nuevos minerales que por la conquista de estos Nacionales [en las] Provincias Internas hay muy ricos y abundantes minerales de plata y oro, que por la ferocidad de los infieles e indios bárbaros no se pueden trabajar ni disfrutar".

Hace referencia también a "varios fondos con destino de Misiones de Infieles" contenidos en testamentos y legados piadosos, que también menciona el padre Alberola, que pudiera el rey mandar se aplicaran sus réditos para la fundación del Colegio. Cita ampliamente cláusulas del testamento del capitán don Francisco de Zúñiga, empresario minero en Nueva España, acusando a sus albaceas de haber malversado dichos fondos. Su afán se explaya a tal grado que cita, igualmente, cláusulas del testamento de don Hernando Cortés, poniendo en duda el dicho de sus herederos de que no había ya nada que testar.

Al momento de la presentación del proyecto ante las autoridades reales, el fraile ya había convenido apoyos importantes con doña Ana María de Yraeta y Ganuza, integrante de una prominente familia española de comerciantes y viuda de don Cosme de Mier y Trespalacios, oidor decano de la Audiencia de México. La cercanía de doña María con el escultor Manuel Tolsá, ${ }^{66}$ quien diseñó el sepulcro de su

66 Soriano, "La huerta del Colegio de San Gregorio", p. 141. Langue, "De la munificencia a la ostentación", menciona que ésta era hija de don Francisco Ignacio de Yraeta, comerciante y empresario prominente entre la élite novohispana. Ana María de Yraeta es reconocida por TAYLOR, "La Virgen de Guadalupe”, p. 233, como la promotora más abierta y persistente de Nuestra Señora de los Remedios para guerrera patrona de los realistas y de su reconocimiento como Generala de las Armas por parte del Ayuntamiento de la Ciudad de México. 
esposo y recibió apoyo en metálico del oidor en vida, explica la autoría de los planos del Colegio de Misioneros. ${ }^{67}$

Doña María de Yraeta se comprometió a construir el Colegio en Nuestra Señora de los Remedios, además de trasladar desde España a 20 misioneros que participarían en el proyecto. Al parecer los regidores de la ciudad de México se negaron a aceptar la solicitud de la viuda para la construcción del edificio, aun cuando don Pedro Caso, dueño de la hacienda de San Nicolás, cuyas tierras lindaban con los cimientos del Santuario de los Remedios, hizo donación del terreno que se requiriera para la construcción.

La evidente cercanía de fray Mariano con la élite española en el virreinato seguramente puede explicarse por sus relaciones familiares en la Nueva España. Era miembro de una importante familia española radicada en Aguascalientes. Su hermano Jacinto López y Pimentel había llegado a la villa como receptor de alcabalas en 1795 . Años más tarde, aparece como dueño de una fábrica de paños de lana, que llegó a contar con 350 obreros, en la que se trabajaban 5000 arrobas de lana anualmente y cuyo principal cliente fue el ejército realista. ${ }^{68}$ Tomás, otro de sus hermanos, fue un político destacado que fungió como regidor, diputado, senador y coronel de la milicia, condecorado por Santa Anna y Maximiliano. ${ }^{69}$

\footnotetext{
${ }^{67}$ En Orozco y Berra, Apéndice al Diccionario Universal, p. 305, se anota que en los festejos organizados en la ciudad de México en 1803 por la revelación de la que sería la escultura de Fernando IV, destaca el banquete ofrecido por Cosme de Mier en honor de don Manuel Tolsá y su esposa doña Luisa Sanz; el escultor recibió de manos de Ana María Yraeta un tejo de oro, "del peso de 15 marcos; dando con este generoso hecho la prueba más convincente de su amor al rey”.

68 Gómez Serrano, Aguascalientes, pp. 141-142.

69 Semo, "Francisco Pimentel”, p. 476.
} 


\section{EL DICTAMEN DEL PROYECTO}

Cuando el obispo de Oaxaca y arzobispo electo de México, don Antonio Bergosa y Jordán (1748-1819), ${ }^{70}$ emitió en 1813 el dictamen solicitado por don José de Limonta, ministro de la Gobernación de Ultramar, sobre la viabilidad del proyecto de fray Mariano, las condiciones políticas en Nueva España y en la Península no daban opción a un plan que parecía absolutamente descabellado por sus altos costos y dudosos resultados. ${ }^{71}$

En estas circunstancias, el proyecto del dieguino fue duramente atacado: el primado dijo haber consultado al padre provincial de la provincia franciscana de San Diego de México, fray Manuel López Borricón, quien le habló de las grandes cualidades espirituales de fray Mariano, tales como "un celo extraordinario por el servicio de Dios y salvación de las almas que lo constituyen en grado de verdadero escrupuloso" pero, a la vez, detalló algunos problemas de la personalidad del fraile que no le habían permitido acceder a grandes empleos, como la falta de prudencia en su ejercicio de confesor y predicador, al grado de calificarlo "punto menos que demente", ya que pasaba días y noches maquinando y escribiendo sobre proyectos extraordinarios y grandiosos.

70 Hamnett, “Antonio Bergosa y Jordán”, lo define como ilustrado opuesto a la insurgencia y a la independencia de México; fungió como inquisidor general desde 1779 hasta la abolición del Santo Oficio.

${ }^{71}$ El mismo año del dictamen, Antonio Bergosa y Jordán se encontraba en plena actividad contrainsurgente, participando en un frente unido con el virrey Félix María Calleja para derrocar a Morelos y a los otros jefes insurgentes. En este sentido, Morales, "La alta educación de los franciscanos", subraya que "los primeros adversarios de este proyecto fueron los tiempos en que nació", p. 88. 
Además del excesivo juicio sobre la cordura del fraile, un aspecto del dictamen que resulta más que ilustrativo de la postura del primado respecto a los indios "bárbaros y salvajes" que habitaban las Provincias Internas, y que fundamenta el juicio negativo de la empresa propuesta, es el punto nodal del método de conversión planteado sobre la base de la predicación del Evangelio en lenguas nativas: " $\mathrm{mi}$ concepto [es el] de que nunca sería adaptable, útil ni posible una fundación semejante: que con su comercio particular y privado perjudicaría enormemente al comercio en general, y que ni conviene fomentar los idiomas muertos, ni menos los bárbaros y desconocidos de estas provincias como proyectaba". ${ }^{72}$

Tras el fracaso de su proyecto, y luego de manifestar que veía amenazada su vida, por lo que planeaba viajar a Manila, ${ }^{73}$ en 1815 fray Mariano se encontraba viviendo en la villa de Aguascalientes como titular del convento de San Diego. Ese año había organizado a la población para denunciar al virrey Calleja del Rey los abusos del comandante militar de la subdelegación de Aguascalientes, Felipe Pérez de Terán. ${ }^{74}$ Tres años más tarde, en 1818 , se inició un proceso en su contra por provocar disturbios en la villa demandando al cabildo por la solicitud denegada del cobro de los festejos dedicados al santo patrono San Francisco de Asís. ${ }^{75}$

72 Citado por Corvera Poiré, "Soñando con evangelizar".

73 Hernández Almendros, "Un proyecto del Colegio Magno", p. 10.

${ }^{74}$ Gómez y Candía, Los españoles en Aguascalientes, p. 39.

75 BPEJ, Civil, c. 427, exp. 1, f. 121, "Auto seguido contra fray Mariano López y Pimentel, titular del convento de San Diego, acusado de provocar disturbios en la villa de Aguascalientes”, 1818-1820. Gómez SERrANo, Aguascalientes en la historia, p. 239. 
Su hermano, Jacinto López y Pimentel, aparece como regidor decano en el ayuntamiento en 1820, año del fin del auto contra fray Mariano. En 1832, aparece en el acta de bautismo de Francisco Pimentel, segundo Conde de Heras, en la iglesia parroquial de la Asunción, de la ciudad de Aguascalientes, quien fue hijo de su hermano Tomás López y Pimentel y Mariana Heras Soto.

Seguramente existen más datos relacionados con la azarosa vida del fraile en México, pero me ha sido difícil localizar mayor información. El último que situé es su nombre en la lista de españoles exceptuados de la ley de 20 de marzo de 1829 , relativa a la expulsión de los españoles, "por impedimento físico perpetuo", correspondiente a la de enero 23 de $1833 .^{76}$

\section{APUNTES PARA UNA CONCLUSIÓN}

Apenas una década después del dictamen emitido por el arzobispo Bergosa y Jordán, el general Manuel Mier y Terán, en calidad de encargado de la comisión para el reconocimiento de los límites entre Texas y México, describió a los habitantes indios del noreste de México y su relación con los "labradores mexicanos" habitantes de la frontera de Coahuila y Monterrey quienes, aseguraba, "los detestan y desean su exterminio". ${ }^{77}$ El general describió en detalle las características de las "tribus de salvajes conocidos" que habitaban en territorio coahuiltexano, contabilizando a cada una por el número de familias que las conformaban.

\footnotetext{
${ }^{76}$ Véase Arrillaga, Recopilación de leyes, p. 307.

77 Mier y Terán, "Noticia de las tribus salvajes”, p. 53.
} 
No le interesaba simplemente describir los bienes y poblaciones del lugar, sino los males que representaban "los salvajes" frente a la posibilidad de perder el vasto territorio logrado que podría llegar a convertirse en el "jardín agrícola de la República": "solamente la población le falta para serlo, lo mismo que para reducir las hordas salvajes que lo infestan, y que semejantes a animales, parásitos, casi viven a expensas de los presentes labradores". ${ }^{78}$ La idea de "poblar para usar"79 el territorio logrado al norte de la Nueva España, en ese momento daba cuenta de más de dos siglos de intentos por colonizar un espacio que, de entrada, se consideró vacío, no domesticado, habitado por hordas de salvajes incontenibles.

La visión de Mier y Terán es, sin duda, manifestación de una política de poblamiento opuesta a la idea franciscana de transformación de los indios en fieles y vasallos que parte, abiertamente, de una expresa intención de exterminar a los indios, a los que se considera insumisos, como lo expresaron los últimos virreyes novohispanos. El virrey Gálvez, conocedor de la situación en las Provincias Internas, se refiere en 1786 a esta política en las instrucciones que debía observar el comandante general de las Provincias Internas, Ugarte y Loyola: "creo positivamente que el vencimiento de los gentiles consiste en empeñarlos a que ellos mismos entre sí se destruyan"; dos años más tarde, el virrey Flores ordenó que se impusiera la guerra defensiva contra los indios enemigos. ${ }^{80}$

\footnotetext{
78 Berlandier y Chovell, La Comisión de Límites, p. 117.

79 Sobre la noción de “poblar para usar" véase SHERIDan, Anónimos y desterrados.

80 Véase Sheridan, Anónimos y desterrados, pp. 275-276.
} 
En el inventario de la barbarie transformada surgen nuevas categorías clasificatorias, más específicas en tanto formas de organización de jurisdicciones avaladas como espacios de comunidad misional, en abierta competencia con los dueños de las congregas, quienes adaptaron la encomienda basada en el principio del control de la población nativa en el plano territorial o de movilidad: la congregación. ${ }^{81}$ En el contexto de la intervención franciscana lo bárbaro recibe nuevos atributos que establecen diferencias entre lo que permanece y lo que cambia, conforme los misioneros hacen su tarea de redención y buscan clasificaciones que definan el inventario de las reducciones y conversiones, de lo logrado y lo que falta por hacer; tal es, por ejemplo, el uso de las nociones gentil/infiel y apóstata, es decir, las almas ignorantes del Evangelio y las influidas por el demonio que habían desconocido el Evangelio. Cuando el espacio ya era considerado territorio de la corona española, se renovaron las categorías originales -salvaje, bárbaro- expuestas bajo nuevos atributos vinculados a formas bélicas justificadas que sustentarían la reestructuración y organización política del espacio a partir de leyes y reglamentos específicos.

Las crónicas coloniales, tanto militares como civiles y religiosas, construyeron así representaciones diversas sobre los nativos que sin duda respondían a intereses y

${ }^{81}$ El uso del término "congrega" proviene de la idea de juntar a los indios en un mismo lugar y fue empleado principalmente en el Nuevo Reino de León, como una forma jurídica de mantener el derecho de encomienda cuando ésta fue abolida por real cédula en 1672, disponiendo a cambio la congregación de indios bajo el amparo del congregador, que se comprometía a educarlos en la fe y a pagar con el régimen de "vara" los trabajos que hicieran a su favor. 
necesidades prácticas derivadas de las relaciones complejas con sujetos sociales adversos a sus intenciones civilizatorias. Esto se hace evidente en la documentación de uso corriente, en la que es común encontrar pugnas y desacuerdos de larga duración, entre autoridades militares y religiosas, sobre la potestad y control de los nativos y la definición de políticas de asentamiento y jurisdicción. Sin embargo, la representación de los indios como sujetos a transformar no difiere entre intereses y necesidades ya que son estos, precisamente, materia prima de sus empresas: los salvajes se transforman en neófitos, sujetos a misión, o en enemigos de la corona sujetos a represión, pero no pierden nunca su calidad de bárbaros irremediables. Solo desaparecen de los escenarios de guerra y conversión cuando dejan sus grupos y se borran sus nombres de los inventarios, o cuando se transforman en cristianos, siempre bajo el riesgo de la apostasía, o se unen a otros grupos que con el tiempo también desaparecerán de los inventarios de las empresas civilizatorias.

En este sentido, el proyecto del dieguino da cuenta de los últimos tramos del proceso de secularización del espacio misional pero, sobre todo, es la síntesis de un proceso de evangelización o conquista espiritual que, en su complejidad, revela la construcción del objeto de conversión que se delinea en el tiempo y que va y viene entre la racionalidad, la humanidad de los indios, su salvajismo y su barbarie, sin perder de vista que se trataba de un cúmulo de infieles que conformaron el alma de la utopía misional: eran todos un otro redimible.

Ese otro tomó formas tan diversas que empezó a adquirir reconocimiento en la diferencia: la lengua, la vestimenta, el estilo de las armas, el territorio donde vivía, las alianzas, 
las discordias, etc. Las clasificaciones empezaron a tomar nombre dando lugar a una diversidad tal que los afanes misioneros se centraron en salvarse a sí mismos del agreste espacio, y en catequizar día a día a las "naciones" de indios que lograban reducir por temporadas. En el inventario final muchos grupos dejaron de ser sujetos de misión por veleidosos, mentirosos o, en el peor de los casos, por representar una amenaza a la vida.

El proyecto de fray Mariano retorna al origen de los empeños misioneros por transformar la infidelidad antes de perderla a manos del demonio, fiel enemigo de la empresa misionera. Al final, los indios inscritos en el proyecto de fray Mariano son tanto gentiles como idólatras, paganos e infieles y, junto con los nativos de Asia, conforman un mundo de almas que es menester convertir a la fe y la civilización por su propio bien, y el de la conciencia del fraile, en un último intento por mantener vigente el orden cultural que lo cobija.

\section{SIGLAS Y REFERENCIAS}

AGI Archivo General de Indias, Sevilla, España.

AGOFM Archivio Generale OFM, Curia Generale dei Frati Minori OFM, Roma, Italia.

AHN Archivo Histórico Nacional, España.

BDH Biblioteca Digital Hispánica.

BNE Biblioteca Nacional de España, Madrid, España.

BPEJ Biblioteca Pública del Estado de Jalisco, México.

Alba-Koch, Beatriz de

"La grandeza mexicana y los aportes asiáticos a la Nueva España: lujo, 'mestizaje cultural' y espiritualidad”, en Maurya e INsúA, 2011, pp. 1732. 
Alcocer, José Antonio OFM

Bosquejo de la historia del Colegio de Nuestra Señora de Guadalupe y sus misiones, año de 1788, México, Porrúa, 1958.

Armas Asín, Fernando (ed.)

Angeli Novi. Prácticas evangelizadoras, representaciones artísticas y construcciones del catolicismo en América (Siglos XVIIXX), Perú, Pontificia Universidad Católica del Perú, 2004.

Arricivita, Juan Domingo

Crónica seráfica y apostólica del Colegio de Propaganda Fide de la Santa Cruz de Querétaro en la Nueva España, dedicada al Santísimo Patriarca el Señor San Joseph. Escrita por el P. Fr. Juan Domingo Arricivita, Predicador Apostólico, ex-Prefecto, y Comisario habitual de las Misiones, Escritor Titular del Seminario, y su mas afecto Hijo, Segunda parte, México, Felipe de Zúñiga y Ontiveros, 1792.

Arrillaga, Basilio José

Recopilación de leyes, decretos, bandos, reglamentos, circulares y providencias de los supremos poderes y otras autoridades de la República Mexicana [de enero de 1832 a marzo de 1833], México, Imprenta de J. M. Fernández de Lara, 1836.

Ashfield, William Rey

"Arquitectura ilustrada en Río de la Plata: el proyecto para una Casa de Misericordia en Montevideo", en Humanidades, 6: 1 (2006), pp. 59-68.

Berlandier, Luis y Rafael Chovell

La Comisión de Límites. Diario de Viaje [1850], Monterrey, Cuadernos del Archivo General del Estado de Nuevo León, núm. 39, 1989.

Calleja del Rey, Félix María

"Informe sobre la Colonia del Nuevo Santander y Nuevo Reino de León. 1795”, en Actas, México, Dirección General de In- 
vestigaciones Humanísticas, Universidad Autónoma de Nuevo León (Serie Documentos), 1978, vol. 3.

Carrillo Cázares, Alberto

El debate sobre la Guerra Chichimeca, 1531-1585, México, El Colegio de Michoacán, El colegio de San Luis Potosí, 2000, vol. I.

Castro, F. Vicente y José Luis Rodríguez Molinero

Bernardino de Sabagún, el primer antropólogo en Nueva España (siglo XVI), Salamanca, Universidad de Salamanca, 1986.

Corsi, Elisabetta

¿“'Obreros de la viña’ o savants? Los misioneros de la Compañía de Jesús en China: entre evangelización y mediación cultural”, en Estudios de Asia y África, 43: 3 (137) (2008), pp. 545-566.

Órdenes religiosas entre América y Asia. Ideas para una historia misionera de los espacios coloniales, México, El Colegio de México, 2008.

Corvera Poiré, Marcela

"Estudio histórico de la familia de franciscanos descalzos en la Provincia de San Diego de México, siglos xvi-xx", tesis de doctorado en historia, Madrid, Universidad Complutense, 1995.

"Soñando con evangelizar: el colegio de infieles proyectado por fray Mariano López Pimentel (1808-18013)”, en Gaceta del Centro de Estudios Históricos del Porfiriato (CEHIPO), 47 (2001), pp. 38-44.

Cramaussel, Chantal

La provincia de Santa Bárbara en Nueva Vizcaya, Chihuahua, Secretaría de Educación y Cultura, Gobierno del Estado de Chihuahua, 2004.

Deeds, Susan

Defiance and Deference in Mexico's Colonial North, Austin, University of Texas Press, 2003. 
DingPing, Shen

"La relación entre la Iglesia mexicana y la evangelización en China en los siglos XVI y XVII. Un estudio comparativo sobre sus estrategias”, en Estudios de Asia y África, 35: 1(111) (2000), pp. 47-75.

Domínguez Reboiras, Fernando

“El 'cuidado y curiosidad' de los franciscanos de Nueva España por las lenguas indígenas y su contexto político”, en OESTERREICHER y SCHMIDT-RIESE, 2010, pp. 302-330.

Duve, Thomas

"Derecho canónico y la alteridad indígena: los indios como neófitos", en Oesterreicher y Schmidt-Riese, 2010, pp. 73-90.

EscANDELl Bonet, Bartolomé

Teoría del discurso historiográfico, Oviedo, Universidad de Oviedo, 1992.

Escandón, Patricia (ed.)

Crónica de Alonso de la Rea, México, El Colegio de Michoacán, 1996.

Espinosa, Isidro Félix de OFM

Chronica Apostólica y Seraphica de todos los Colegios de Propaganda Fide de esta Nueva España, México, Viuda de Joseph Bernardo de Hogal, 1746.

Falcón, Romana y Raymond Buve

Don Porfirio presidente..., nunca omnipotente. Hallazgos, reflexiones y debates, 1876-1911, México, Universidad Iberoamericana, 1998.

Florescano, Enrique

Memoria mexicana, México, Fondo de Cultura Económica, 2004. 
Gómez Canedo, Lino

Evangelización y conquista: experiencia franciscana en Hispanoamérica, México, Biblioteca Porrúa, 1977.

Gómez Serrano, Jesús

Aguascalientes en la historia, 1786-1920, México, Gobierno del Estado de Aguascalientes, Instituto de Investigaciones Dr. José María Luis Mora, 1988, vol. II.

Gómez Serrano, Jesús y Humberto Candía Goytya

Los españoles en Aguascalientes durante la época colonial. Origen, desarrollo e influencia de una minoría, México, El Colegio de Jalisco, Fomento Cultural Banamex, Universidad Autónoma de Aguascalientes, 2002.

Hamnett, Brian Robert

“Antonio Bergosa y Jordán (1748-1819), obispo de México: ¿ilustrado?, ¿reaccionario?, ¿contemporizador y oportunista?”, en Historia Mexicana, LIx: 1(233) (jul.-sep. 2009), pp. 117-136.

Hernández Alméndros, Victoria

"Un proyecto del Colegio Magno de Misioneros en Méjico", Anuario de Estudios Americanos, Ix (1952), pp. 415-429.

Hernández Silva, Héctor Cuauhtémoc

"Los pueblos yaquis y los circuitos económicos de Sonora a principios del siglo XIX”, en Desacatos, 10 (2002), pp. 94-112.

HiLlock, Laura

"La frontera que nos une: proyecto para educar al bárbaro, México, 1807”, en Brocar, 30 (2006), pp. 65-83.

Hu-DeHart, Evelyn

"Rebelión campesina en el noroeste: los indios yaquis de Sonora, 1740-1976”, en KATZ, 1988, pp. 135-163. 


\section{Inventario General de Manuscritos}

Inventario General de Manuscritos de la Biblioteca Nacional, X (3027-5699), Madrid, Ministerio de Cultura, Dirección General de Libros y Bibliotecas, 1984.

JoHn, Elizabeth A. H.

"The Multilingual Vision of Fray Pimentel", en Journal of the Southwest, 34: 2 (1992), pp. 152-165.

Katz, Friederich (comp.)

Revuelta, rebelión y revolución. La lucha rural en México del siglo XVI al siglo XX, Nueva York, Princeton University Press, 1988.

\section{Ku Menghsuan}

"La huella de los franciscanos en China: los principales documentos en chino", en http://www.traduccion-franciscanos. uva.es/archivos/Ku.pdf

Langue, Frédérique

"De la munificencia a la ostentación”, en Nuevo Mundo Mundos Nuevos [Online], Library of the Authors of the Center, Langue, Frédérique, http://nuevomundo.revues.org/642;

DOI: 10.4000/nuevomundo.642. Consultado el 5 de diciembre

LETONDAL, Claudio Francisco

Relación de las tribulaciones de los fieles y de las necesidades del sagrado ministerio para conservar la semilla de la Fe y propagarla en las partes orientales de la Asia. Dedicada a la Gloriosisima patrona universal de la América Septentrional la Santísima Virgen de Guadalupe, Nuestra Señora, México, Imprenta de Don Mariano de Zúñiga y Ontiveros, 1804.

Maurya, Vibha y Mariela Insúa (eds.)

Actas del I Congreso Ibero-asiático de Hispanistas. Siglo de Oro e hispanismo general, Delhi, 9-12 de noviembre de 2010, 
Pamplona, publicaciones digitales del GRIso, Servicio de $\mathrm{Pu}-$ blicaciones de la Universidad de Navarra, 2011.

Mayer, Alicia (coord.)

México en tres momentos: 1810-1910-2010. Hacia la conmemoración del Bicentenario de la Independencia y el Centenario de la Revolución Mexicana. Retos y perspectivas, prólogo de Juan Ramón de la Fuente, México, Universidad Nacional Autónoma de México, 2010, vol. 2.

Mendieta, Jerónimo de

Historia eclesiástica indiana, Madrid, Red Ediciones, www. linkua.com

Mier y Terán, Manuel

"Noticia de las tribus de salvajes conocidos que habitan en el Departamento de Tejas, y del número de familias de que consta cada tribu, puntos en que habitan y terrenos en que acampan (1828)", en Nueva Antropología, v: 18 (1982), pp. 53-68.

Morales, Francisco OFM

"De la utopía a la locura. El Asia en la mente de los franciscanos de Nueva España: del siglo XVI al xIX”, en Corsi (coord.), 2008, pp. 57-83.

"La alta educación de los franciscanos para los indígenas", en Diario de Campo, 3 (2011), pp. 84-89.

O’Crouley, Pedro Alonso

Idea compendiosa del Reino de la Nueva España (manuscrito de 1774), México, Talleres Gráficos de Contabilidad Ruf, 1975.

Oesterreicher, Wulf y Roland Schmidt-Riese (eds.)

Esplendores y miserias de la evangelización de América. Antecedentes europeos y alteridad, Berlín, De Gruyter, 2010.

Orozco y Berra, Manuel (coord.)

Apéndice al Diccionario Universal de Historia y Geografía, 
México, Imprenta de J. M. Andrade y F. Escalante, 1856, t. II, IX de la obra.

OrTelli, Sara

Trama de una guerra conveniente: Nueva Vizcaya y la sombra de los apaches (1748-1790), México, El Colegio de México, 2007.

Osante, Patricia

Orígenes del Nuevo Santander, 1748-1772, México, Universidad Nacional Autónoma de México, Universidad Autónoma de Tamaulipas, 1997.

Palau y Dulcet, Antonio

Manual del librero hispanoamericano: bibliografía general española e hispanoamericana desde la invención de la imprenta hasta nuestros tiempos, Oxford, Dolphin Book Company, 1964, vol. 16.

Palomera SJ, Esteban J.

Fray Diego Valadés, OFM. Evangelizador humanista de la Nueva España. El hombre, su época y su obra, México, Universidad Iberoamericana, 1988.

PAstor, Beatriz

El jardín y el peregrino. El pensamiento utópico en América Latina (1492-1695), México, Difusión Cultural unam, 1999.

PÉrez, Joseph

Teresa de Ávila y la España de su tiempo, Madrid, Ediciones Algaba, 2007.

Ponce Alcocer, María Eugenia (introducción, transcripción y notas)

Cartas desde India y China de los misioneros jesuitas. Siglos XVII-XVIII, México, Universidad Iberoamericana, 2007. 
Radding, Cynthia

Wandering Peoples. Colonialism, Ethnic Spaces and Ecological Frontiers in Northwestern Mexico, 1700-1850, Durham y Londres, Duke University Press, 1997.

Revillagigedo, Juan Vicente Güemes, segundo Conde de

Informes sobre las misiones -1793-e Instrucción reservada al Marqués de Branciforte-1794-, introducción y notas de José Bravo Ugarte, México, Jus, 1966.

Semo, Enrique

Historia de la cuestión agraria mexicana. El siglo de la bacienda, 1800-1900, México, Siglo Veintiuno Editores, 1988.

"Francisco Pimentel, precursor del neoliberalismo", en FALcón y Buve (comps.), 1998, pp. 473-496.

Sheridan, Cecilia

Anónimos y desterrados. La contienda por el "sitio que llaman de Quauyla”. Siglos XVI-XVIII, México, Centro de Investigaciones y Estudios Sociales en Antropología Social, Miguel Ángel Porrúa, 2000.

Fronterización del espacio hacia el norte de la Nueva Espa$\tilde{n} a$, México, Centro de Investigaciones y Estudios Sociales en Antropología Social, Instituto de Investigaciones Dr. José María Luis Mora.

Sheridan, Thomas E. y Thomas H. Naylor (eds.)

Rarámuri. A Tarabumara Colonial Chronicle, 1607-1791, Flagstaff, Northland Press, 1979.

Sheridan, Thomas E. y Nancy J. Parezo (eds.)

Paths of Life: American Indians of the Southwest and Northern Mexico, Tucson, University of Arizona Press, 1996.

Soriano Valdez, María Cristina

"La huerta del Colegio de San Gregorio, asiento del taller de Manuel Tolsá y su transformación en fundición de cañones, 
1796-1815”, en Historia Mexicana, LIx: 4 (236) (abr.-jun. 2010), pp. 1401-1432.

TAYLOR, William B.

"La Virgen de Guadalupe, Nuestra Señora de los Remedios y la cultura política del periodo de Independencia”, en MAYER, 2010, pp. 213-240.

Torre Curiel, José Refugio de la

"Características de la empresa misional franciscana en Sonora al finalizar el siglo xviII”, en Armas Asín, 2004, pp. 49-64.

Torres Lanzas, Pedro

Relación descriptiva de los mapas, planos, E de México y Floridas existentes en el Archivo General de Indias, Sevilla, Imprenta Mercantil, 1900, t. II.

VÁzquez Loya, Dizan

Las misiones franciscanas en Chibuabua. Pistas y referencias para su investigación, Chihuahua, Universidad Autónoma de Ciudad Juárez, 2004.

Venegas Delgado, Hernán y Carlos Manuel Valdés Dávila

La ruta del horror. Prisioneros indios del noreste novohispano llevados como esclavos a La Habana, Cuba. (Finales del siglo XVIII a principios del siglo XIX), México, Universidad Autónoma de Coahuila, Plaza y Valdés, 2013.

Weber, David J.

La frontera norte de México, 1821-1846. El sudoeste norteamericano en su época mexicana, México, Fondo de Cultura Económica, 2005.

Bárbaros. Los españoles y sus salvajes en la era de la Ilustración, Barcelona, Crítica, 2007. 
